\title{
Effect of sinking spring phytoplankton blooms on lipid content and composition in suprabenthic and benthic invertebrates in a cold ocean coastal environment
}

\author{
Christopher C. Parrish, Don Deibel, Raymond J. Thompson
}

Ocean Sciences Centre, Memorial University of Newfoundland, St. John's, Newfoundland and Labrador, A1C 5S7, Canada

\begin{abstract}
Lipids were measured in 19 suprabenthic and benthic invertebrate taxa from 5 phyla to determine their responses to a sinking spring diatom bloom. In Conception Bay, as in many areas of coastal Newfoundland, Canada, benthic organisms experience sub-zero temperatures year round. Among specimens collected at depths between 210 and $220 \mathrm{~m}$, the small mysid Erythrops erythrophtalma had, on average, the highest lipid concentration (6\% of wet weight), while a holothurian (Order Apodida) had the lowest $(0.3 \%)$. In E. erythrophtalma, $73 \%$ of the lipids were found in the neutral fraction, while in the sea cucumber $68 \%$ were polar lipids. The euphausiid Thysanoessa raschii had the highest proportion of essential $\omega 3$ fatty acids ( $41 \%$ total fatty acids) while the holothurian had the lowest $(21 \%)$. Pseudocalanus spp. showed the highest mean value for the $\mathrm{C}_{16}$ polyunsaturated fatty acid (PUFA) ratio indicative of lipids from nutrient-replete diatoms. The amphipods Acanthostepheia malmgreni and Anonyx spp. responded immediately to each spring bloom with increased total and neutral lipid contents. The mysid Pseudomma truncatum also showed a transient increase in total lipid content, but this occurred much later in the summer. However, $P$. truncatum, together with the decapod Pandalus borealis, the mysid Mysis mixta, and the polar bivalve Yoldia hyperborea, did respond immediately based on increased proportions of $\omega 3$ fatty acids, while the asteroid Ctenodiscus crispatus showed increased $\omega 3$ fatty acid proportions in its gonads much later. The chaetognath Parasagitta elegans differed from most other species in that it maintained very similar total lipid and $\mathrm{C}_{16}$ PUFA proportions throughout the sampling period, suggesting little direct response to the bloom. Thus, we found a variable response to the bloom with respect to phenology, even within orders, which depended upon feeding behaviour and gonadogenesis.
\end{abstract}

KEY WORDS: Fatty acids • Bacillariophyceae · Polychaeta • Copepoda • Malacostraca • Protobranchia $\cdot$ Echinodermata $\cdot$ Chaetognatha

\section{INTRODUCTION}

Phytoplankton blooms occur when photosynthetic production temporarily exceeds loss processes, including mixing, sinking and consumption by heterotrophs. If there is a considerable time lag between the bloom and the increase of major grazers such as copepods, increased aggregation of phytoplankton cells can lead to vertical export of organic matter (Wassmann 1997), so that the benthos may become a major beneficiary of the bloom. This occurs in cold water fjord-like bays around the island of Newfoundland (Pomeroy et al. 1991, Parrish 1998, Thompson et al. 2008). Lipids are an important component of this vertical flux (Parrish et al. 2005). They are reduced compounds with a very high energy content, which makes them an important energy source for heterotrophic organisms. Neutral lipids such as wax esters and triacylglycerols are used as energy stores, whereas polar lipids such as phospholipids and glycolipids are critical constituents of membranes. Certain components of neutral and polar lipids, the $\omega 3$ fatty acids, are also essential for animal 
survival and growth (Ackman \& Kean-Howie 1994, Xu et al. 1994). They are precursors of highly bioactive metabolites and are required for normal membrane structure and function, especially at low temperatures (Hall et al. 2002). Thus, the Arctic marine realm, in which Newfoundland is located (Spalding et al. 2007), is an area of particular interest for work with marine fatty acids and lipid classes. Indeed, the study of food web lipids in the cold waters off the coast of Newfoundland is important and timely given current problems with the ground fishery (e.g. Parsons 2005, Martínez-Murillo \& Haedrich 2007) and the increasing interest in aquaculture in this area (e.g. Tlusty et al. 2005, Parrish et al. 2007a).

In the present study, we examined the responses of suprabenthic and benthic invertebrates at $>200 \mathrm{~m}$ depth near, on and in the seafloor to the sinking spring phytoplankton bloom in Conception Bay, Newfoundland, Canada. Lipid classes and fatty acids were measured in 19 taxa experiencing sub-zero water temperatures year round. The benthos in this region may be very efficient at assimilating bloom material. Pomeroy et al. (1991) found lower bacterial production rates in the epibenthic flocculent layer than in sediment trap material at the same low temperature and attributed this to rapid processing of bloom material by benthic invertebrates. Parrish (1998) found that only $3 \%$ of the lipid flux through the water column was preserved in sediments in nearby Trinity Bay, Newfoundland, and the value for $\omega 3$ fatty acid preservation was 10 times lower (Budge \& Parrish 1998).

Our aims were to (1) identify and quantify the main lipid groups in a wide variety of suprabenthic and benthic invertebrates in Conception Bay, and (2) determine the influence of deposited spring bloom material on the amount and quality of these lipids.

\section{MATERIALS AND METHODS}

Sampling site. Conception Bay is one of several large, fjord-like bays on the Atlantic coast of Newfoundland (Fig. 1). It is about $100 \mathrm{~km}$ long and $30 \mathrm{~km}$ wide, with a maximum depth of about $300 \mathrm{~m}$ and a sill depth of $170 \mathrm{~m}$.

Water column sampling. CTD casts were conducted from March 1996 to August 1998 using a Seabird SBE25 CTD with a SeaTech fluorometer. The fluorometer was calibrated against Conception Bay chlorophyll a (chl a) determinations yielding: extracted chl a $\left(\mu \mathrm{g} \mathrm{l}^{-1}\right)=0.4 \times$ relative fluorescence measurement +0.3 $\left(\mathrm{r}^{2}=0.65, \mathrm{n}=253\right.$ : R. Tian, pers. comm.). Unsmoothed fluorescence data were processed using Surfer and SigmaPlot contouring programs.

Benthic sampling. Over the 3 yr of the study, specimens of invertebrates were collected with a dredge
(Stead \& Thompson 2003) and an opening-and-closing, modified Macer-GIROQ epibenthic sled (Choe \& Deibel 2000, Richoux et al. 2004a) (Table 1). The $1.2 \mathrm{~m}$ wide dredge was fitted with a $2.54 \mathrm{~cm}$ mesh net and towed from the RV 'Karl \& Jackie' for $20 \mathrm{~min}$. The sled, which had a $500 \mu \mathrm{m}$ mesh liner, was towed for $20 \mathrm{~min}$ at 1.5 to 2 knots at a depth of between 210 and $220 \mathrm{~m}$, collecting organisms living within $60 \mathrm{~cm}$ of the bottom. Animals were allowed to depurate overnight. They were not sorted by sex, and were not always identified

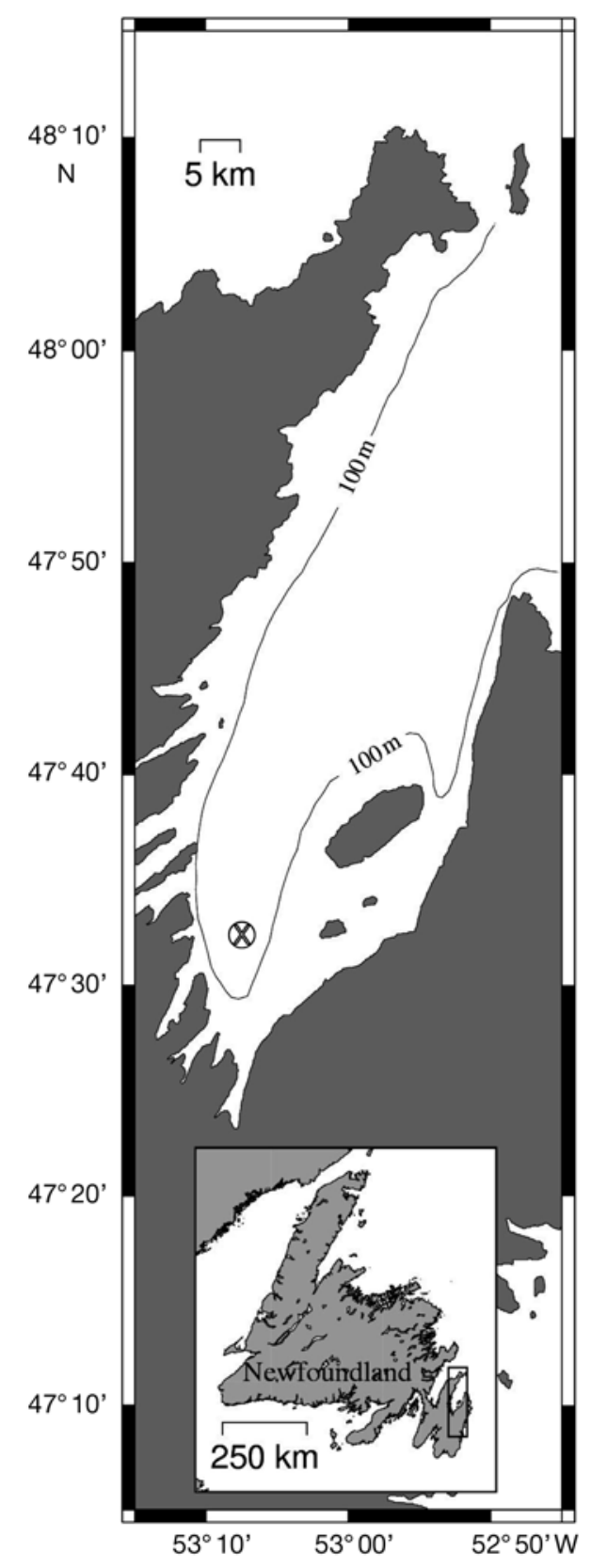

Fig. 1. Station location $(\otimes)$ on the southeast coast of the island of Newfoundland. Water column depth is $230 \mathrm{~m}$ and the bottom is $\mathrm{mud} / \mathrm{silt}$ 
to species level. For example, Anonyx spp. samples were probably $A$. sarsi, but they could also have included $A$. ochoticus and A. makarovi.

Lipid analyses. Lipids were extracted from whole animals (Table 1) and analysed based on Parrish (1999). In the case of the asteroid Ctenodiscus crispatus, lipids were determined in excised gonads and, in May to July 1997, in stomachs. Briefly, all samples were extracted in cold chloroform:methanol (2:1 v/v) using a modified Folch procedure. Lipid classes in the extracts were determined with the ChromarodIatroscan thin layer chromatography with flame ionization detection (TLC-FID) system. Separation of lipid classes on the rods was carried out in a 3-step development system. The first separation consisted of 2 developments ( $25 \mathrm{~min}$ followed by $20 \mathrm{~min}$ ) in hexane:diethyl ether:formic acid (98.95:1:0.05 v/v/v). The second separation consisted of a 40 min development in hexane: diethyl ether:formic acid (79:20:1 v/v/v). The last separation consisted of two 15 min developments in $100 \%$ acetone, followed by two 10 min developments in chloroform:methanol:water (5:4:1 v/v/v). After each separation, the rods were scanned using different scan lengths for each step: Iatroscan settings of PPS (partial pyrolysis selection) 22 and 11 for the first 2 chromatograms, respectively, and a full scan for the last. Lipid classes were summed to calculate total lipid content as $\%$ wet weight ( $\%$ WW). To determine individual fatty acids, samples were transmethylated with $10 \%$ boron trifluoride/methanol at $85^{\circ} \mathrm{C}$ before separation of the derivatives by gas chromatography (GC). Water was then added and the upper, organic layer withdrawn and placed in a $2 \mathrm{ml}$ vial. The sample volume was adjusted to 0.5 to $2.0 \mathrm{ml}$, of which $1 \mu \mathrm{l}$ was injected into a Varian 3400 GC using a Varian 8100 AutoSampler. Fatty acids were separated on a $30 \mathrm{~m}$ Omegawax 320 column (Supelco) and were identified mainly by comparison to a comprehensive standard (Supelco 37 component FAME mix) and by reference to Ackman (1986).

Table 1. Suprabenthic and benthic invertebrates collected for lipid determination from Conception Bay, Newfoundland between March 1996 and August 1998. Each sample extracted consisted of 1 to 30 specimens, depending on size and lipid content. Values are means $\pm \mathrm{SD}$, or $\frac{1}{2}$ range when $\mathrm{n}=2$; - : not determined

\begin{tabular}{|c|c|c|c|c|c|}
\hline Taxon & Number of specimens & Sex o/o' & Number of samples & Size $(\mathrm{mm})$ & Weight $(g)$ \\
\hline \multicolumn{6}{|l|}{ Phylum Annelida } \\
\hline \multicolumn{6}{|l|}{ Polychaeta } \\
\hline Nephtys incisa & 2 & - & 2 & - & $2.14 \pm 1.59$ \\
\hline Polynoidae & 2 & - & 2 & - & $0.63 \pm 0.05$ \\
\hline Unidentified polychaetes & 10 & - & 10 & - & $0.53 \pm 0.57$ \\
\hline \multicolumn{6}{|l|}{ Phylum Arthropoda } \\
\hline \multicolumn{6}{|l|}{ Copepoda } \\
\hline Pseudocalanus spp. & - & Mainly o & 4 & - & - \\
\hline \multicolumn{6}{|l|}{ Amphipoda } \\
\hline Acanthostepheia malmgreni & 88 & Mainly op & 30 & $22.6 \pm 6.82$ & $0.27 \pm 0.20$ \\
\hline Anonyx spp. & 66 & - & 21 & $18.8 \pm 5.82$ & $0.28 \pm 0.14$ \\
\hline Arrhis phyllonyx & 9 & - & 4 & $21.5 \pm 3.50$ & $0.12 \pm 0.02$ \\
\hline Gammaridae & 1 & - & 1 & 20 & 0.11 \\
\hline Parathemisto spp. & 13 & - & 4 & $16.5 \pm 9.19$ & $0.09 \pm 0.10$ \\
\hline \multicolumn{6}{|l|}{ Euphausiacea } \\
\hline Thysanoessa raschii & 7 & - & 2 & $34 \pm 26$ & $0.09 \pm 0.01$ \\
\hline \multicolumn{6}{|l|}{ Decapoda } \\
\hline Eualus macilentus & 6 & - & 6 & 17 & $1.38 \pm 1.68$ \\
\hline Pandalus borealis & 38 & Mainly o & 34 & $20.3 \pm 13.9$ & $1.14 \pm 1.68$ \\
\hline \multicolumn{6}{|l|}{ Mysidacea } \\
\hline Erythrops erythrophtalma & 30 & Mainly o & 6 & $8.77 \pm 5.25$ & $0.02 \pm 0.003$ \\
\hline Mysis mixta & 42 & Mainly o & 11 & $17.9 \pm 10.1$ & $0.12 \pm 0.05$ \\
\hline Pseudomma truncatum & 135 & Mainly o & 18 & $14.0 \pm 1.89$ & $0.03 \pm 0.01$ \\
\hline \multicolumn{6}{|l|}{ Phylum Mollusca } \\
\hline \multicolumn{6}{|l|}{ Protobranchia } \\
\hline Yoldia hyperborea & 23 & - & 23 & - & $1.47 \pm 0.73$ \\
\hline \multicolumn{6}{|l|}{ Phylum Echinodermata } \\
\hline \multicolumn{6}{|l|}{ Asteroidea } \\
\hline Ctenodiscus crispatus & 28 & - & 28 & $57.7 \pm 5.54$ & $1.22 \pm 0.62$ \\
\hline \multicolumn{6}{|l|}{ Holothuroidea } \\
\hline Apodida & 2 & - & 2 & $25.0 \pm 0.00$ & $0.40 \pm 0.13$ \\
\hline \multicolumn{6}{|l|}{ Phylum Chaetognatha } \\
\hline Parasagitta elegans & 63 & - & 12 & $32.3 \pm 2.85$ & $0.06 \pm 0.02$ \\
\hline
\end{tabular}



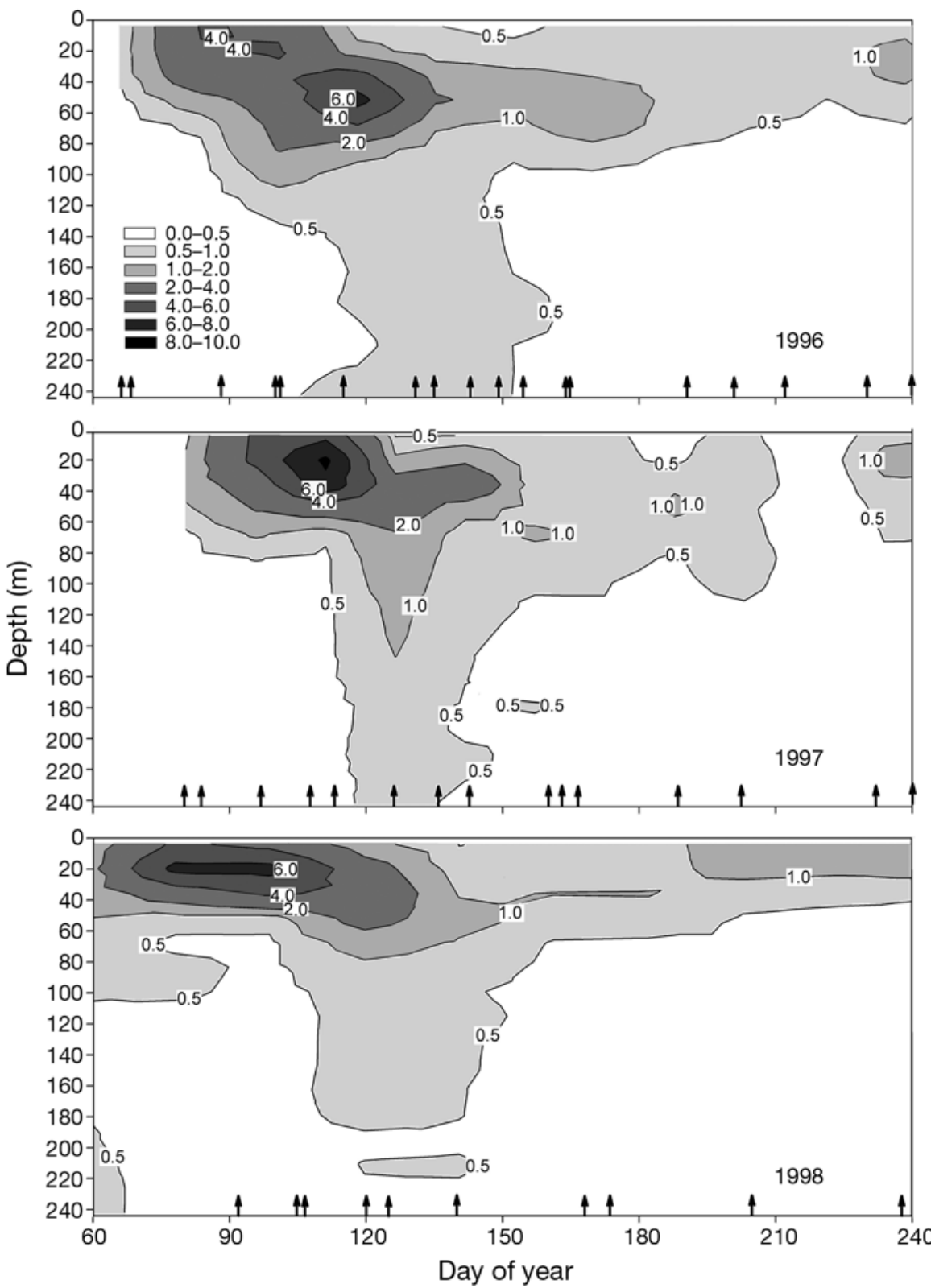

Fig. 2. Spring diatom blooms in Conception Bay, Newfoundland. Data from a SeaTech fluorometer are contoured in relative fluorescence units. Arrows indicate dates of casts

version 13.1. A correlation matrix was used, and coefficients and scores were grouped by cluster analysis using single linkage. To determine stability of the patterns, PCAs were also carried out on transformed data and results were compared. The PCA patterns achieved with arcsine transformed data were very similar to PCA results from untransformed data. In another analysis, percent total lipid (\%TL) and percent total fatty acid (\% TFA) data were converted to $\%$ wet weight (\%WW), and while the spatial distributions of the coefficients and the scores did change, mainly as a result of the 20 -fold range in total lipid concentrations, many of the groupings determined by cluster analysis remained.

\section{RESULTS AND DISCUSSION}

\section{Hydrographic conditions}

Temperature in the water column over the deepest part of Conception Bay ranged from -1.5 to $15.9^{\circ} \mathrm{C}$ during the sampling period. In March of each year, it was $<0^{\circ} \mathrm{C}$ throughout the water column and remained sub-zero below $75 \mathrm{~m}$ water depth until at least midAugust each year. Below $150 \mathrm{~m}$, the temperature was $<0^{\circ} \mathrm{C}$ and salinity was $>31.8$ throughout the study period. In situ fluorescence data were used to track the progress of the spring diatom bloom (Fig. 2). The timing of the start, the maximum, and the arrival of the bloom material at the benthos (Table 2) was determined using unsmoothed data processed by contouring programs. In 1996, the bloom started on 15 March (2.0 relative fluorescence unit,

Statistical analyses. Two-sample and one-sample Student's $t$-tests were conducted using Minitab version 13.1. One-way analysis of variance (ANOVA) was performed using SigmaStat 2.03. All data were tested for normality and equal variance. Where these tests failed, a Kruskal-Wallis one-way ANOVA on ranks was done. Groups that differed were identified using Tukey's test following ANOVA and Dunn's test after the KruskalWallis ANOVA on ranks. Linear and polynomial regressions were performed in SigmaPlot 7.1. Principal components analyses (PCA) were done with Minitab
RFU, contour), the first arrival of the bloom material at the benthos was 25 dater ( 0.5 contour), and the bloom maximum (centre of 6.0 contour) occurred $40 \mathrm{~d}$ after the start of the bloom. In 1997, the bloom started on 28 March (2.0 contour), the first arrival of the bloom material at the benthos was $31 \mathrm{~d}$ later ( 0.5 contour), and the bloom maximum (centre of 6.0 contour) occurred $25 \mathrm{~d}$ after the start of the bloom. Finally, in 1998 the bloom started on 2 March, the first arrival of the majority of the bloom material at the benthos was $57 \mathrm{~d}$ later, and the bloom maximum occurred $44 \mathrm{~d}$ after the start of the 
bloom. The interannual range in the time of the start of the bloom was $26 \mathrm{~d}$, but the range in the time of peak magnitude was only $10 \mathrm{~d}$ (Table 2 ). At the end of each time-series, there was a small increase in fluorescence in surface waters (1.0 contour) that lasted until the end of August each year (Fig. 2).

\section{Major lipid groups in suprabenthic and benthic invertebrates}

The lipid content and composition of the 19 suprabenthic and benthic invertebrate taxa was quite variable (Table 3). Coefficients of variation (CVs) among the grand means for lipid ratios and lipid classes (total lipids, neutral lipids, lipolysis index) ranged from 32 to
$72 \%$. CVs for ratios and groups of fatty acids (total polyunsaturated-to-total saturated fatty acids [P/S] ratio, $\mathrm{C}_{16}$ polyunsaturated fatty acid [PUFA] ratio, bacterial fatty acids, PUFA, $\omega 3$ fatty acids) ranged from 14 to $67 \%$. Nearly half the taxa from the 5 phyla sampled showed extreme values for one or more of the lipid variables: the unidentified polychaetes, the copepod Pseudocalanus spp., the arctic amphipod Arrhis phyllonx, the gammarid, the euphausiid Thysanoessa raschii, the small mysid Erythrops erythrophtalma, Mysis mixta, the apodid holothurian, and the chaetognath Parasagitta elegans. The latter 3 taxa also had extreme proportions of major lipid classes (Table 4). Even more taxa had extreme values of the major individual fatty acids derived from the acyl lipids (Table 5), demonstrating the diversity of lipids in this ecosystem.

Table 2. Timing (date and day of year) of the spring diatom bloom in Conception Bay, Newfoundland

\begin{tabular}{|lccccc|}
\hline Year & \multicolumn{2}{c}{ Time of onset } & \multicolumn{2}{c|}{ Time of peak } & \multicolumn{2}{c}{ Time of first arrival on seafloor } \\
\hline 1996 & 15 March & 75 & 24 April & 115 & 9 April \\
1997 & 28 March & 87 & 22 April & 112 & 28 April \\
1998 & 2 March & 61 & 15 April & 105 & 118 \\
Interannual range (d) & & 26 & & 10 & 28 April \\
\hline
\end{tabular}

Table 3. Lipid composition of benthic and suprabenthic invertebrates from Conception Bay. TL: total lipids (sum of Iatroscan determined lipid classes); WW: wet weight; NL: neutral lipids: hydrocarbons, wax and steryl esters, ketones, triacylglycerols, free fatty acids, alcohols, sterols, diacylglycerols; LI: lipolysis index (FFA + ALC [acyl lipids + ALC] ${ }^{-1}$ ) $\times 100$; bacterial fatty acids: i15:0 + ai15:0 + 15:0 + i16:0 + ai16:0+i17:0 + ai17:0+17:0; P/S ratio: polyunsaturated fatty acids/saturated fatty acids; PUFA: $\Sigma$ polyunsaturated fatty acids; $\omega 3$ fatty acids: $\Sigma \omega 3$ PUFA; $C_{16}$ PUFA ratio: 16:2 $\omega 4+16: 3 \omega 4+16: 4 \omega 3+16: 4 \omega 1(16: 0+16: 1 \omega 7+16: 1 \omega 5+$ $16: 2 \omega 4+16: 3 \omega 4+16: 4 \omega 3+16: 4 \omega 1)^{-1} \times 100$. TFA: total fatty acids. Values are mean \pm SD when $\mathrm{n} \geq 3$ or mean $\pm 1 / 2$ range when $\mathrm{n}=2$; highest and lowest values in each column are in bold $_{i}{ }^{*}$ : significantly different from column mean

\begin{tabular}{|c|c|c|c|c|c|c|c|c|}
\hline & $\begin{array}{c}\text { TL } \\
(\% \mathrm{WW})\end{array}$ & $\begin{array}{c}\mathrm{NL} \\
(\% \mathrm{TL})\end{array}$ & $\begin{array}{l}\text { LI } \\
(\%)\end{array}$ & $\begin{array}{l}\text { Bacterial fatty } \\
\text { acids ( } \% \text { TFA) }\end{array}$ & $\begin{array}{l}\mathrm{P} / \mathrm{S} \\
\text { ratio }\end{array}$ & $\begin{array}{l}\text { PUFA } \\
(\% \text { TFA }) \quad \text { a }\end{array}$ & $\begin{array}{c}\omega 3 \text { fatty } \\
\text { acids ( } \% \text { TFA) }\end{array}$ & $\begin{array}{l}\mathrm{C}_{16} \text { PUFA } \\
\text { ratio }(\%)\end{array}$ \\
\hline Nephtys incisa & $0.78 \pm 0.10$ & $38.7 \pm 6.33$ & $5.15 \pm 3.11$ & $3.63 \pm 0.54$ & $2.14 \pm 0.30$ & $38.7 \pm 0.06$ & $33.0 \pm 0.04$ & $10.3 \pm 0.52$ \\
\hline Polynoidae & $0.63 \pm 0.05$ & $38.3 \pm 6.09$ & $3.71 \pm 2.05$ & $2.34 \pm 0.47$ & $2.35 \pm 0.34$ & $45.4 \pm 7.33$ & $40.0 \pm 6.47$ & $6.82 \pm 0.11$ \\
\hline Unidentified polychaetes & $1.26 \pm 0.90$ & $55.3 \pm 21.0$ & $14.2 \pm 14.4$ & $6.45 \pm 4.83^{*}$ & $1.84 \pm 0.45$ & $36.3 \pm 6.78$ & $30.4 \pm 6.31$ & $9.43 \pm 3.77$ \\
\hline Pseudocalanus spp. & $1.45 \pm 0.86$ & $74.2 \pm 19.5$ & $0.62 \pm 0.42^{*}$ & * $0.92 \pm 0.09^{*}$ & $2.86 \pm 1.04$ & $42.0 \pm 10.1$ & $35.1 \pm 9.12$ & $22.7 \pm 6.76^{*}$ \\
\hline $\begin{array}{l}\text { Acanthostepheia } \\
\text { malmgreni }\end{array}$ & $0.97 \pm 0.48^{*}$ & $54.1 \pm 13.2$ & $9.95 \pm 4.81^{*}$ & * $2.73 \pm 1.21$ & $2.63 \pm 0.57^{*}$ & * $43.9 \pm 4.59^{*}$ & * $38.2 \pm 4.36^{*}$ & ${ }^{*} 4.52 \pm 2.01^{*}$ \\
\hline Anonyx spp. & $3.83 \pm 1.69^{*}$ & $75.2 \pm 10.9^{*}$ & $* 3.61 \pm 4.40^{*}$ & * $1.79 \pm 0.38^{*}$ & $1.78 \pm 0.27^{*}$ & ${ }^{*} 31.9 \pm 3.94 *$ & $1^{*} 27.5 \pm 3.79^{*}$ & * $4.04 \pm 1.43^{*}$ \\
\hline Arrhis phyllonyx & $1.78 \pm 1.49$ & $52.4 \pm 15.2$ & $5.25 \pm 2.55$ & $3.53 \pm 0.43$ & $3.24 \pm 0.43^{*}$ & $50.3 \pm 1.82 *$ & $2^{*} 33.5 \pm 3.37$ & $5.34 \pm 1.53$ \\
\hline Gammaridae & $0.76^{*}$ & $40.8^{*}$ & $11.9^{*}$ & 2.77 & 1.91 & $42.8^{*}$ & $36.9^{*}$ & $3.95^{*}$ \\
\hline Parathemisto spp. & $2.45 \pm 0.19$ & $54.5 \pm 12.7$ & $4.00 \pm 3.59$ & $1.35 \pm 0.51^{*}$ & $1.96 \pm 0.18$ & $41.0 \pm 1.80$ & $37.1 \pm 1.68$ & $4.06 \pm 1.09$ \\
\hline Thysanoessa raschii & $4.10 \pm 1.80$ & $36.9 \pm 3.54$ & $8.85 \pm 0.52$ & $1.11 \pm 0.28$ & $1.89 \pm 0.46$ & $44.9 \pm 5.73$ & $41.0 \pm 5.74^{*}$ & $4.10 \pm 0.37$ \\
\hline Eualus macilentus & $2.63 \pm 0.67$ & $67.9 \pm 9.32$ & $7.98 \pm 2.89$ & $1.98 \pm 0.25$ & $1.79 \pm 0.23$ & $32.8 \pm 3.64^{*}$ & $* 28.5 \pm 3.56$ & $4.09 \pm 1.02$ \\
\hline Pandalus borealis & $1.95 \pm 0.84$ & $71.3 \pm 15.8^{*}$ & $* 12.8 \pm 6.82^{*}$ & $* 2.37 \pm 0.96$ & $1.70 \pm 0.40^{*}$ & $* 34.5 \pm 5.69 *$ & * $29.7 \pm 6.11$ & $4.40 \pm 1.47^{*}$ \\
\hline Erythrops erythrophtalma & $5.86 \pm 1.44^{*}$ & $73.4 \pm 5.46^{*}$ & $2.77 \pm 2.78$ & $1.38 \pm 0.44^{*}$ & $1.47 \pm 0.33^{*}$ & * $32.1 \pm 4.86^{*}$ & * $28.6 \pm 4.53$ & $5.79 \pm 2.49$ \\
\hline Mysis mixta & $4.86 \pm 2.09^{*}$ & $76.2 \pm 9.82^{*}$ & * $2.05 \pm 1.13^{*}$ & $* 1.73 \pm 0.50$ & $1.78 \pm 0.33$ & $38.4 \pm 4.45$ & $33.5 \pm 3.76$ & $10.9 \pm 3.47$ \\
\hline Pseudomma truncatum & $3.57 \pm 1.76^{*}$ & $64.1 \pm 10.7$ & $2.80 \pm 2.35^{*}$ & * $1.69 \pm 0.50^{*}$ & $1.59 \pm 0.57^{*}$ & * $33.6 \pm 7.47^{*}$ & $7 * 29.2 \pm 7.03$ & $5.21 \pm 1.35$ \\
\hline Yoldia hyperborea & $1.21 \pm 0.60^{*}$ & $56.1 \pm 9.34$ & $4.54 \pm 4.83^{*}$ & * $2.85 \pm 1.47$ & $1.96 \pm 0.76$ & $40.3 \pm 11.2$ & $33.4 \pm 9.36$ & $9.62 \pm 3.96$ \\
\hline Ctenodiscus crispatus & $4.74 \pm 2.01^{*}$ & $69.1 \pm 19.3$ & $3.78 \pm 2.58$ & $5.35 \pm 0.62^{*}$ & $3.21 \pm 0.97^{*}$ & * $38.7 \pm 6.86$ & $26.7 \pm 3.34$ & $18.6 \pm 17.1$ \\
\hline Apodida & $0.29 \pm 0.13$ & $32.3 \pm 7.64$ & $5.90 \pm 0.99$ & $6.45^{*}$ & $1.15^{*}$ & 31.1* & $20.8^{*}$ & $13.0^{*}$ \\
\hline Parasagitta elegans & $1.07 \pm 0.44^{*}$ & $15.1 \pm 7.68^{*}$ & * $3.70 \pm 2.03$ & $2.39 \pm 1.42$ & $1.93 \pm 0.35$ & $36.6 \pm 4.47$ & $33.7 \pm 4.58$ & $4.37 \pm 1.09^{*}$ \\
\hline Mean & 2.33 & 55.1 & 5.97 & 2.78 & 2.06 & 38.7 & 32.5 & 7.96 \\
\hline $\mathrm{SD}$ & 1.68 & 17.4 & 3.86 & 1.66 & 0.56 & 5.36 & 5.06 & 5.32 \\
\hline CV $(\%)$ & 72.1 & 31.7 & 64.7 & 59.7 & 27.2 & 13.8 & 15.6 & 66.9 \\
\hline
\end{tabular}


Table 4. Major lipid classes ( $>35 \%$ in at least one taxon) in benthic and suprabenthic invertebrates from Conception Bay in comparison with the same lipid classes in particles collected at a depth of $220 \mathrm{~m}$ during the spring bloom (Parrish et al. 2005). Data are \% total lipids \pm SD when $n \geq 3$ or $1 / 2$ range when $\mathrm{n}=2$. Column maxima and minima are in bold and are significantly different from column means $(\mathrm{p}<0.05)$

\begin{tabular}{|lccc|}
\hline & $\begin{array}{c}\text { Wax ester/ } \\
\text { steryl ester }\end{array}$ & $\begin{array}{c}\text { Triacyl- } \\
\text { glycerol }\end{array}$ & $\begin{array}{c}\text { Phospho- } \\
\text { lipid }\end{array}$ \\
\hline Settling particles & $10.2 \pm 8.28$ & $19.7 \pm 5.35$ & $16.2 \pm 3.51$ \\
Nephtys incisa & $3.52 \pm 1.10$ & $13.5 \pm 3.79$ & $53.4 \pm 12.7$ \\
Polynoidae & $5.54 \pm 2.76$ & $15.6 \pm 3.32$ & $58.2 \pm 5.89$ \\
Unidentified polychaetes & $12.6 \pm 22.5$ & $15.0 \pm 14.4$ & $36.6 \pm 20.5$ \\
Pseudocalanus spp. & $\mathbf{3 6 . 1} \pm \mathbf{3 1 . 8}$ & $17.7 \pm 22.7$ & $27.6 \pm 19.6$ \\
Acanthostepheia malmgreni & $2.52 \pm 2.38$ & $28.4 \pm 12.1$ & $42.5 \pm 11.4$ \\
Anonyx spp. & $1.78 \pm 2.15$ & $\mathbf{6 2 . 6} \pm \mathbf{1 1 . 3}$ & $22.3 \pm 6.05$ \\
Arrhis phyllonyx & $1.15 \pm 1.15$ & $37.2 \pm 21.6$ & $40.5 \pm 14.9$ \\
Gammaridae & 3.06 & 12.6 & 53.2 \\
Parathemisto spp. & $12.8 \pm 9.03$ & $30.1 \pm 6.79$ & $34.5 \pm 8.72$ \\
Thysanoessa raschii & $1.38 \pm 1.38$ & $17.7 \pm 3.19$ & $58.9 \pm 0.43$ \\
Eualus macilentus & $0.44 \pm 0.38$ & $43.2 \pm 4.40$ & $31.7 \pm 9.13$ \\
Pandalus borealis & $1.92 \pm 1.48$ & $44.3 \pm 16.6$ & $24.5 \pm 9.11$ \\
Erythrops erythrophtalma & $8.85 \pm 1.67$ & $58.5 \pm 9.19$ & $21.4 \pm 5.35$ \\
Mysis mixta & $6.55 \pm 2.58$ & $59.7 \pm 5.85$ & $\mathbf{2 1 . 5} \pm \mathbf{5 . 1 3}$ \\
Pseudomma truncatum & $7.71 \pm 2.20$ & $48.1 \pm 9.25$ & $32.4 \pm 6.89$ \\
Yoldia hyperborea & $0.17 \pm 0.24$ & $38.8 \pm 7.76$ & $37.8 \pm 6.59$ \\
Ctenodiscus crispatus & $0.11 \pm 0.11$ & $58.7 \pm 2.38$ & $25.0 \pm 0.44$ \\
Apodid holothurian & $\mathbf{0 . 0 0} \pm \mathbf{0 . 0 0}$ & $18.7 \pm 5.57$ & $56.6 \pm 8.42$ \\
Parasagitta elegans & $0.18 \pm 0.30$ & $\mathbf{1 . 8 6} \pm \mathbf{1 . 1 5}$ & $\mathbf{7 9 . 6} \pm \mathbf{5 . 5 5}$ \\
Taxa mean & 5.61 & 32.8 & 39.9 \\
SD & 8.45 & 19.1 & 16.1 \\
CV (\%) & 151 & 58.2 & 40.4 \\
& & & \\
\hline
\end{tabular}

There was also a wider range in CVs among grand means for the major lipid classes and fatty acids. More extreme lipid class and fatty acid proportions occurred in the echinoderm taxa than in any other taxon: the distributions of major fatty acids in the mud star Ctenodiscus crispatus and the apodid holothurian were different from other taxa and from each other.

The carnivorous polychaete $\mathrm{Ne}$ phtys incisa is unique in this data set: none of the variables for this species listed in Table 3 are significantly different from the grand mean across species, nor does it have an extreme value for any of the major lipid classes or fatty acids (Tables $4 \& 5$ ), suggesting a lipid content and composition that could be considered to be typical for this environment.

\section{Total lipid and neutral lipids}

The grand mean, wet weightspecific total lipid content (\% WW) for

Table 5. Major fatty acids ( $>5 \%$ in at least one taxon) in benthic and suprabenthic invertebrates from Conception Bay in comparison with the same fatty acids in particles collected at a depth of $220 \mathrm{~m}$ during the spring bloom (Parrish et al. 2005). Data are \% total fatty acids \pm SD. Column maxima and minima are in bold and are significantly different from column means $(\mathrm{p}<0.01)$

\begin{tabular}{|c|c|c|c|c|c|c|c|c|c|}
\hline & $14: 0$ & $16: 0$ & $16: 1 \omega 7$ & $18: 1 \omega 9$ & $18: 1 \omega 7$ & $20: 1 \omega 9$ & $20: 4 \omega 6$ & $20: 5 \omega 3$ & $22: 6 \omega 3$ \\
\hline Settling particles & $7.28 \pm 2.06$ & $12.8 \pm 2.01$ & $22.1 \pm 4.12$ & $4.56 \pm 1.61$ & $1.91 \pm 0.92$ & $1.29 \pm 0.92$ & $0.70 \pm 0.80$ & $12.7 \pm 6.47$ & $2.48 \pm 0.96$ \\
\hline Nephtys incisa & $2.05 \pm 1.09$ & $11.1 \pm 0.93$ & $4.61 \pm 0.59$ & $6.43 \pm 0.88$ & $5.41 \pm 0.02$ & $5.30 \pm 0.03$ & $1.49 \pm 0.33$ & $19.2 \pm 0.77$ & $9.68 \pm 0.42$ \\
\hline Polynoidae & $4.68 \pm 0.35$ & $10.6 \pm 0.22$ & $4.23 \pm 0.93$ & $10.6 \pm 1.67$ & $2.80 \pm 2.80$ & $7.58 \pm 0.48$ & $0.80 \pm 0.05$ & $18.1 \pm 2.67$ & $18.4 \pm 4.17$ \\
\hline Unidentified polychaetes & $3.32 \pm 2.52$ & $12.3 \pm 2.17$ & $8.86 \pm 5.48$ & $6.39 \pm 5.54$ & $4.83 \pm 2.99$ & $4.20 \pm 2.48$ & $1.17 \pm 0.59$ & $18.0 \pm 2.81$ & $8.64 \pm 4.56$ \\
\hline Pseudocalanus spp. & $6.91 \pm 3.53$ & $7.54 \pm 1.33$ & $15.1 \pm 4.82$ & $8.27 \pm 3.89$ & $1.03 \pm 1.14$ & $4.05 \pm 6.68$ & $0.30 \pm 0.09$ & $21.3 \pm 4.41$ & $9.29 \pm 5.94$ \\
\hline $\begin{array}{l}\text { Acanthostepheia } \\
\text { malmgreni }\end{array}$ & $2.04 \pm 0.91$ & $12.3 \pm 2.23$ & $3.77 \pm 1.50$ & $12.9 \pm 2.32$ & $6.90 \pm 1.42$ & $2.67 \pm 0.97$ & $2.29 \pm 0.78$ & $20.3 \pm 1.62$ & $15.3 \pm 2.40$ \\
\hline Anonyx spp. & $3.13 \pm 0.81$ & $13.3 \pm 1.91$ & $9.87 \pm 1.23$ & $20.0 \pm 3.29$ & $4.74 \pm 0.74$ & $6.19 \pm 2.08$ & $1.28 \pm 0.29$ & $13.4 \pm 2.11$ & $11.2 \pm 1.23$ \\
\hline Arrhis phyllonyx & $1.77 \pm 0.42$ & $11.1 \pm 2.90$ & $4.93 \pm 2.65$ & $9.25 \pm 2.38$ & $8.27 \pm 0.66$ & $1.97 \pm 0.78$ & $12.0 \pm 2.47$ & $17.3 \pm 1.61$ & $11.3 \pm 3.47$ \\
\hline Gammaridae & 2.28 & 17.7 & 3.95 & 15.5 & 8.02 & 1.04 & 2.34 & 21.8 & 12.7 \\
\hline Parathemisto spp. & $4.78 \pm 0.60$ & $14.0 \pm 3.14$ & $8.14 \pm 1.22$ & $11.7 \pm 4.32$ & $3.34 \pm 2.10$ & $6.80 \pm 4.90$ & $0.41 \pm 0.03$ & $16.4 \pm 2.72$ & $17.0 \pm 2.26$ \\
\hline Thysanoessa raschii & $5.00 \pm 0.90$ & $17.9 \pm 1.98$ & $7.16 \pm 3.19$ & $7.20 \pm 0.20$ & $8.11 \pm 0.70$ & $2.18 \pm 1.06$ & $0.97 \pm 0.33$ & $22.3 \pm 0.17$ & $16.5 \pm 4.95$ \\
\hline Eualus macilentus & $2.47 \pm 0.39$ & $13.3 \pm 0.45$ & $9.39 \pm 1.27$ & $14.4 \pm 1.08$ & $9.06 \pm 0.55$ & $3.91 \pm 0.72$ & $1.77 \pm 0.38$ & $15.6 \pm 1.57$ & $11.7 \pm 2.87$ \\
\hline Pandalus borealis & $4.45 \pm 0.94$ & $13.7 \pm 1.97$ & $9.09 \pm 1.93$ & $12.0 \pm 2.10$ & $5.72 \pm 1.25$ & $4.99 \pm 1.52$ & $1.83 \pm 1.09$ & $15.3 \pm 2.09$ & $12.2 \pm 1.74$ \\
\hline $\begin{array}{l}\text { Erythrops } \\
\text { erythrophtalma }\end{array}$ & $8.52 \pm 1.28$ & $12.0 \pm 0.56$ & $10.8 \pm 0.90$ & $17.7 \pm 2.84$ & $3.45 \pm 1.66$ & $3.81 \pm 0.42$ & $0.55 \pm 0.13$ & $14.2 \pm 3.55$ & $11.9 \pm 1.99$ \\
\hline Mysis mixta & $8.48 \pm 1.23$ & $12.1 \pm 0.92$ & $11.8 \pm 2.44$ & $13.1 \pm 2.66$ & $2.34 \pm 0.93$ & $4.52 \pm 1.18$ & $0.59 \pm 0.07$ & $19.6 \pm 3.72$ & $10.3 \pm 1.96$ \\
\hline Pseudomma truncatum & $6.32 \pm 1.68$ & $14.2 \pm 1.30$ & $10.6 \pm 1.83$ & $14.8 \pm 2.57$ & $3.42 \pm 1.24$ & $5.58 \pm 1.39$ & $1.06 \pm 0.56$ & $14.6 \pm 1.89$ & $12.3 \pm 2.44$ \\
\hline Yoldia hyperborea & $4.00 \pm 0.99$ & $13.2 \pm 1.66$ & $12.0 \pm 3.278$ & $5.53 \pm 3.30$ & $5.30 \pm 3.22$ & $3.58 \pm 1.33$ & $1.64 \pm 0.33$ & $24.0 \pm 6.88$ & $4.21 \pm 1.18$ \\
\hline Ctenodiscus crispatus & $1.63 \pm 0.60$ & $4.96 \pm 0.99$ & $4.27 \pm 1.41$ & $8.04 \pm 2.96$ & $8.62 \pm 3.32$ & $16.9 \pm 2.24$ & $6.65 \pm 1.57$ & $21.6 \pm 3.62$ & $2.31 \pm 0.52$ \\
\hline Apodida & 5.48 & 17.7 & 10.3 & 2.59 & 0.00 & 0.91 & 4.26 & 15.2 & 3.78 \\
\hline Parasagitta elegans & $4.11 \pm 0.34$ & $13.1 \pm 0.67$ & $9.34 \pm 0.34$ & $11.2 \pm 0.90$ & $2.56 \pm 2.05$ & $5.02 \pm 1.10$ & $0.33 \pm 0.07$ & $15.1 \pm 1.03$ & $15.4 \pm 1.29$ \\
\hline Taxa mean & 4.29 & 12.7 & 8.32 & 10.9 & 4.94 & 4.80 & 2.20 & 18.1 & 11.3 \\
\hline SD & 2.13 & 3.17 & 3.26 & 4.46 & 2.69 & 3.44 & 2.83 & 3.17 & 4.41 \\
\hline CV $(\%)$ & 49.8 & 24.9 & 39.2 & 40.8 & 54.3 & 71.7 & 128 & 17.6 & 39.1 \\
\hline
\end{tabular}


all taxa over the entire study period was $2.3 \pm 1.7 \%$ (Table 3). The variability in total lipid content among taxa was the highest of all lipid ratios and groups, and half the taxa had a mean total lipid content significantly higher or lower than the grand mean value. The taxa with the highest content were the mysids Erythrops erythropthalma and Mysis mixta, and those with the lowest were the apodid holothurian and the polynoid polychaete. Some of the variability in weightspecific lipid content among the wide phyletic range of organisms is due to skeletal differences between calcareous and non-calcareous taxa. The range in mean lipid content for all calcareous taxa was 0.8 to $5.9 \%$ (13 Crustacea and the mud star Ctenodiscus crispatus), while the range for non-calcareous taxa was 0.3 to $1.3 \%$ (6 polychaete worm, shucked bivalve, holothurian and chaetognath taxa). Assuming that dry weight is $20 \%$ of wet weight for calcareous taxa (Billones et al. 1999) and $3.4 \%$ of wet weight for noncalcareous taxa (Young et al. 1996), the range in total dry weight-specific lipid content (lipid \% of dry weight, \% DW) for all calcareous taxa becomes 3.8 to $29 \%$, and for the non-calcareous taxa 8.5 to $37 \%$. Thus, on a dry weight basis, the ranges in total lipid content of the calcareous and non-calcareous taxa overlap to a great extent.

Mean neutral lipid proportions ranged from 15\% TL for Parasagitta elegans to $76 \%$ TL for Mysis mixta (Table 3). There was a strong relationship between variability in total lipid content and neutral lipid proportion, with significant differences in wet weightspecific total lipid content in 5 of the 6 cases, in which the neutral lipid proportion was significantly different from the mean for all taxa (Table 3). The 3 taxa with the lowest mean neutral lipid proportions belonged to 3 different phyla (chaetognaths, echinoderms and arthropods: 15 to $37 \%$ TL), while the 3 taxa with the highest neutral lipid proportions were all crustaceans (74 to $76 \% \mathrm{TL}$ ), but belonged to 3 different orders (Table 3).

In general, the mysids, which are important prey for fish, contained the largest amounts of total and neutral lipids. Overall, Erythrops erythrophtalma contained the highest amount of lipids (5.9\% WW), while the sea cucumber contained the lowest $(0.3 \%$ WW), which reflects the water content but may also be a result of low concentrations of lipids in sediments (Parrish 1998) and a non-selective feeding behaviour. In E. erythrophtalma, $73 \%$ of the lipids were in the neutral fraction, while in the sea cucumber $68 \%$ were in the polar (membrane) fraction.

Total lipids and neutral lipids in Ctenodiscus crispatus were within the same range as that found for the mysids. The C. crispatus lipid values in Table 3 were derived by combining data from gonads and
Table 6. Lipid composition of Ctenodiscus crispatus from Conception Bay, Newfoundland. LI: lipolysis index $=$ (free fatty acids + alcohols / acyl lipids + alcohols $) \times 100$; $\mathrm{P} / \mathrm{S}$ ratio $=$ polyunsaturated fatty acids / saturated fatty acids. ${ }^{*} \mathrm{p}<0.05$, ${ }^{* *} \mathrm{p}<0.01,{ }^{* * *} \mathrm{p}<0.001$

\begin{tabular}{|c|c|c|c|c|}
\hline & \multicolumn{2}{|c|}{ _ Gonad __ } & \multicolumn{2}{|l|}{ _ Stomach _ } \\
\hline & Mean \pm SD & $\mathrm{n}$ & Mean \pm SD & $\mathrm{n}$ \\
\hline Total lipids (\% WW) & $6.00 \pm 5.10$ & 24 & $3.98 \pm 0.96$ & 8 \\
\hline LI (\%) & $1.89 \pm 3.07^{*}$ & 24 & $5.16 \pm 5.16^{*}$ & 8 \\
\hline $\mathrm{P} / \mathrm{S}$ ratio & $4.16 \pm 1.17^{* *}$ & 28 & $2.79 \pm 0.70^{* *}$ & 8 \\
\hline $\mathrm{C}_{16}$ PUFA ratio (\%) & $26.1 \pm 10.9$ & 27 & $21.3 \pm 12.3$ & 8 \\
\hline $18: 1 \omega 9 / 18: 1 \omega 7$ & $0.18 \pm 0.07^{* * *}$ & 21 & $0.35 \pm 0.07^{* * *}$ & 4 \\
\hline
\end{tabular}

stomachs (Table 6) from the same animal (4 specimens from 2 sampling days in spring 1997). Despite a similar feeding habitat, these data contrast with the other echinoderm sampled, the apodid holothurian, which had low levels of total lipids and neutral lipid proportions (Table 3). It is possible that this difference was in part due to the different life history stage examined in each case (e.g. adult vs. juvenile) or to different feeding modes (e.g. subsurface vs. surface: Neto et al. 2006). Nevertheless, both echinoderms had high proportions of bacterial fatty acids (Table 3), suggesting significant dietary intake (Sargent et al. 1983).

The euphausiid Thysanoessa raschii was also rich in total lipids but not neutral lipids, whereas the amphipod Anonyx spp. contained a high proportion of neutral lipids but less total lipid. T. raschii from Conception Bay had a similar lipid concentration to conspecifics from the Clyde Estuary (3.2\% WW; Henderson et al. 1982), but lower neutral lipids than the Scottish samples $(78 \% \mathrm{TL})$; however, the lipid class composition is seasonally variable, with polar lipids reaching maximum proportions in spring (Falk-Petersen et al. 1981). Assuming a water content of $80 \%$, the total dry weight-specific lipid content of $T$. raschii in Conception Bay (ca. $20 \%$ DW) is also similar to minimum levels found in T. raschii from Norwegian fjords (20 to $25 \%$ DW; Falk-Petersen et al. 2000), which occur post bloom. Lipid concentrations and neutral lipid proportions in Anonyx spp. lie within the ranges that can be calculated from the data of Lehtonen (1996) for another benthic amphipod, Monoporeia affinis. These data yield lipid contents of $\sim 3.8$ to $\sim 11.3 \%$ WW, which are high for benthic crustaceans. In comparison, the amphipod Corophium volutator contains only $1.7 \%$ WW (Napolitano \& Ackman 1989). However, the Amphipoda contain species with a wide variety of feeding behaviours (Blankenship \& Levin 2007), so a wide species-specific range in the acquisition and deposition of high energy lipid compounds is to be expected. 


\section{Major lipid classes}

On average, the major neutral lipids were triacylglycerols, and the major polar lipids were phospholipids (Table 4). The variability in the major lipid classes was higher than in total neutral lipids or total polar lipids, especially in the wax and steryl esters. The very high overall CV $(151 \%)$ in the combined wax ester/steryl ester Iatroscan peak is caused by wax ester storage in Pseudocalanus spp., giving a \% TL value for Pseudocalanus spp. 6-fold higher than the mean for all taxa and 3-fold higher than the average composition in settling particles at $220 \mathrm{~m}$ during the spring bloom. Pseudocalanus spp. also stores triacylglycerol (Fraser et al. 1989), but at about half the level of wax esters. The opposite was the case in Parathemisto spp., with $30 \%$ of the lipid being comprised of triacylglycerol, similar to Parathemisto abyssorum sampled in a northern Norwegian fjord (Falk-Petersen et al. 1987).

For 5 of the 19 species, the triacylglycerol is also a combined lipid class value, but here the second component is distinguishable by Iatroscan. Many of the Polynoidae as well as the amphipod Acanthostepheia malmgreni and the mysids Eualus macilentus and Mysis mixta had small acylated glyceryl ether peaks shouldering on the triacylglycerol peaks. These alkyldiacylglycerols, which are ether analogues of the triacylglycerols, amounted to only about 0.5 to $4 \%$ of the combined triacylglycerol plus alkyldiacylglycerol value. In contrast, almost all of the Ctenodiscus crispatus stomach and gonad samples had significant alkyldiacylglycerol peaks amounting to about $20 \%$ of the combined value. These ether lipids are thought to be major energy reserves in asteroid eggs (Falk-Petersen \& Sargent 1982).

\section{Fatty acids}

The unidentified polychaetes had the highest mean lipolysis index and proportion of bacterial fatty acids, suggesting a strong association with bacterial degradation of lipids. Sediments in this region also have high bacterial fatty acid proportions $(9.8 \pm 1.8 \%$; Budge \& Parrish 1998). The holothurian had equally high proportions of bacterial fatty acids as the polychaetes, and the lowest P/S fatty acid ratio. This ratio is commonly used as a dietary indicator in humans (e.g. Hu et al. 2001) and has also been employed as an indicator of fluidity in mammalian membranes (e.g. Parrish et al. 1997). The same ratio has been used to detect carnivory in krill (Cripps \& Atkinson 2000), a low value of 1.1 suggesting general herbivory. The proportions of both total PUFAs and $\omega 3$ fatty acids in the holothurian were also the lowest among all examined taxa (31 and
$21 \%$, respectively). The nearest relative, Ctenodiscus crispatus, had the next lowest $\omega 3$ fatty acid proportion $(27 \%)$. Generally, $\omega 3$ fatty acids are low in echinoderms (Copeman \& Parrish 2003).

In general, the amphipods and Thysanoessa raschii had the highest proportions of algal-derived $\omega 3$ fatty acids (Table 3). T. raschii prefers phytoplankton to copepods (Sargent \& Falk-Petersen 1981) and had the highest essential $\omega 3$ fatty acid proportion overall (41\% total fatty acids), double that of the sea cucumber. Nonetheless, the range of $\omega 3$ and PUFA proportions across all species is remarkably narrow compared with other variables (Table 3 ) and is consistent with data from further north in coastal Labrador, especially for PUFA proportions $(48 \pm 7 \%$; Copeman $\&$ Parrish 2003). Higher proportions of $\omega 3$ fatty acids and PUFA in a wide variety (16 species) of macroinvertebrates from coastal Labrador compared to Table 3 suggest a corollary to the continuing question concerning the relationship between temperature and total lipid contents of benthos (Clarke 1977, Graeve \& Wehrtmann 2003). PUFA and $\omega 3$ fatty acid proportions may vary latitudinally and may be characteristic of the ecosystem, with both nutritional (e.g. Copeman et al. 2002) and biophysical (e.g. Hall et al. 2002) implications.

Diatoms typically synthesize not only $\omega 3$ fatty acids but also unsaturated fatty acids in which the position of the first double bond can range from the 1st to the 13th carbon with respect to the methyl end, even for a single fatty acid chain length, especially $\mathrm{C}_{16}$. Shin et al. (2000) proposed a 'polyunsaturation index of $\mathrm{C}_{16}$ fatty acids' as an indicator of the physiological status of diatoms. They used the ratio $16: 2 \omega 7+16: 3 \omega 4+16: 4 \omega 1$ to $16: 0+16: 1 \omega 9+16: 1 \omega 7+16: 1 \omega 5+16: 2 \omega 7+16: 3 \omega 4+$

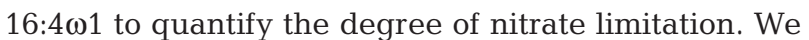
used a slight modification of both the calculation and the name of the ratio (Table 3) to show incorporation of lipids from nutrient-replete diatoms by invertebrates (Shin et al. 2000, Parrish et al. 2005). Our $\mathrm{C}_{16}$ PUFA ratio is defined as the ratio $16: 2 \omega 4+16: 3 \omega 4+16: 4 \omega 3+$ $16: 4 \omega 1$ to $16: 0+16: 1 \omega 7+16: 1 \omega 5+16: 2 \omega 4+16: 3 \omega 4+$

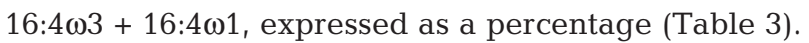
Pseudocalanus spp. showed the highest mean value for this ratio (Table 3) and for 16:1 17 (Table 5), which is consistent with diatoms being a preferred food of Pseudocalanus elongatus (Koski et al. 1998, Cotonnec et al. 2001) and also diatoms triggering the initiation of growth in the vertically migrating $P$. acuspes at the start of the spring bloom (Conover \& Huntley 1991). Pseudocalanus spp. may accumulate wax ester as their major lipid (Table 4) in order to maximize the assimilation rate (Fraser et al. 1989). Pseudocalanus spp. also had the lowest values for the lipolysis index $(0.6 \%)$ and bacterial fatty acids $(0.9 \%)$, distinguishing them from 
all other taxa, especially the gammarid, which had the lowest $\mathrm{C}_{16}$ PUFA ratio.

Only 8 of the examined taxa did not show extreme values for any of the major individual fatty acids (Nephtys incisa, Polychaeta spp., Gammaridae sp., Parathemisto spp., Pandalus borealis, Mysis mixta, Pseudomma truncatum, Parasagitta elegans; Table 5). Over half of the total fatty acid amount in all 19 taxa was accounted for by just 9 fatty acids: the short-chain saturates 14:0 and 16:0, the monoenes 16:1 $107,18: 1 \omega 9$,

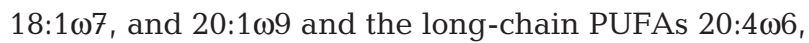

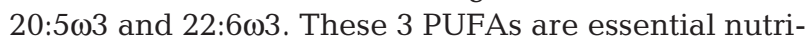
ents in marine food webs (Ackman \& Kean-Howie 1994, Xu et al. 1994, Alkanani et al. 2007) and were present in higher proportions, on average, in the examined taxa than in settling particles at $220 \mathrm{~m}$ water depth during the spring bloom (Table 5). Their proportions correlated significantly with those of 7 minor PUFAs in the Conception Bay invertebrate taxa. Of

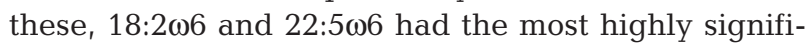
cant correlations ( $\mathrm{p} \leq 0.001)$, which might be related to their having essential fatty acid activity too (Pond et al. 1996, Parrish et al. 2007b).

Eicosapentaenoic acid (EPA, 20:5 $\omega 3$ ) was, on average, the major fatty acid found in all species (18.1 \pm $3.2 \% \mathrm{SD}_{\text {; }}$ Table 5) and was particularly high in the bivalve Yoldia hyperborea, accounting for almost a quarter of the total fatty acids. This proportion is higher than in particles settling to the bottom at Conception Bay (12.7 $\pm 6.47 \%$; Parrish et al. 2005) and much higher than in sediments in this region $(0.77 \pm$ $0.19 \%$; Budge \& Parrish 1998). The EPA content in $Y$. hyperborea is consistent with cold water deposit feeders being able to consume 20:5 $\omega 3$-rich food selectively (McMahon et al. 2006), and it may also reflect conservation of 20:5 $\omega 3$ during metabolism.

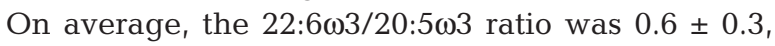
suggesting the dominance of diatom over dinoflagellate-derived fatty acids. In net tow samples from neigh-

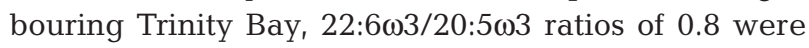
obtained from samples in which centric diatoms dominated, but where dinoflagellates accounted for about $20 \%$ of the algal cells (Budge \& Parrish 1998). This ratio is considered to be important in the nutrition of marine fish, values of 2 or higher being desirable (Copeman et al. 2002, Dwyer et al. 2003, Park et al. 2006). The importance of $22: 6 \omega 3$ in relation to $20: 5 \omega 3$ for these organisms contrasts with the dominance of 20:5 13 in their food web (Table 5), suggesting that there is a mechanism for 'trophic magnification' of $22: 6 \omega 3$ within the food web. It is noteworthy that Parathemisto spp. have slightly more 22:603 than 20:5 $\omega 3$ (Table 5), as they feed mainly on copepods and are themselves an important prey for fish (Scott et al. 1999, Haro-Garay 2003).

\section{Principal components analysis (PCA)}

PCA of the variables in Table 3 allows a simple graphic representation of the entire data set (Fig. 3). Given the large number of samples (cases), there is room to add more observations (variables) than in Table 3 until case and variable numbers are approximately equal. By sequentially adding major fatty acids and lipid classes until the number of variables was equal to the number of cases +1 , it was possible to maximize the amount of variation accounted for by the first 2 principal components. Using the variables in Table 3 plus proportions of the 2 major fatty acids (20:5 $\omega 3$ and 16:0) and the 2 major lipid classes (phospholipid and triacylglycerol), it was possible to account for $59.2 \%$ of the variation with just the first 2 principal components (Fig. 3). Addition of the third principal component raised this value to $75.5 \%$.

The first component (PC1), representing the variation in percentage and ratio data, separates phospholipids and $\omega 3$ fatty acids from triacylglycerol and neutral lipid proportions (Fig. 3a). This indicates that triacylglycerol-dominated neutral lipids generally accounted for high levels of weight-specific total lipids and that $\omega 3$ fatty acids were associated primarily with membranes rather than with lipid storage. PC2 separates the P/S ratio and PUFAs from 16:0 and the lipolysis index, suggesting that animals associated with degraded lipids had low PUFA contents. Cluster analysis of the PC loading coefficients (Fig. 3a) groups the lipolysis index with bacterial fatty acids, indicating that the lipid degradation is microbially mediated. All unsaturation indices cluster together, except for the $\mathrm{C}_{16}$ PUFA ratio, which is located closer to neutral and total lipids because high $\mathrm{C}_{16}$ PUFA ratios are usually associated with high neutral lipid proportions, reflecting storage of fatty acids derived from fresh diatom cells. However, the P/S ratio and the $\mathrm{C}_{16}$ PUFA ratio both load positively on PC3 (Fig. 3a).

Plots of the scores for the first 2 principal components (Fig. 3b) reveal that all polychaetes and most of the amphipods are located in the 2 left quadrants because of high $\omega 3$ fatty acid proportions and/or low triacylglyerol proportions, while all mysids and decapods lie in the right quadrants because of low phospholipid proportions and usually high total lipid concentrations. A major exception is Anonyx spp., which is separate from other amphipods because of its high total lipid, neutral lipid and TAG proportions, likely reflecting foraging flexibility in this order (Blankenship \& Levin 2007). Of the polychaetes, the Polynoidae have the most negative PC1 scores, reflecting their higher PUFA and $\omega 3$ fatty acid proportions and their lower total lipid concentrations and neutral lipid proportions (Table 3). Co-location of Nephtys incisa and Acanthostepheia 
malmgreni on PC1 may reflect amphipod predation by the polychaete (Redmond \& Scott 1989).

Erythrops erythrophtalma has the most positive PC1 score with the highest lipid concentration among these

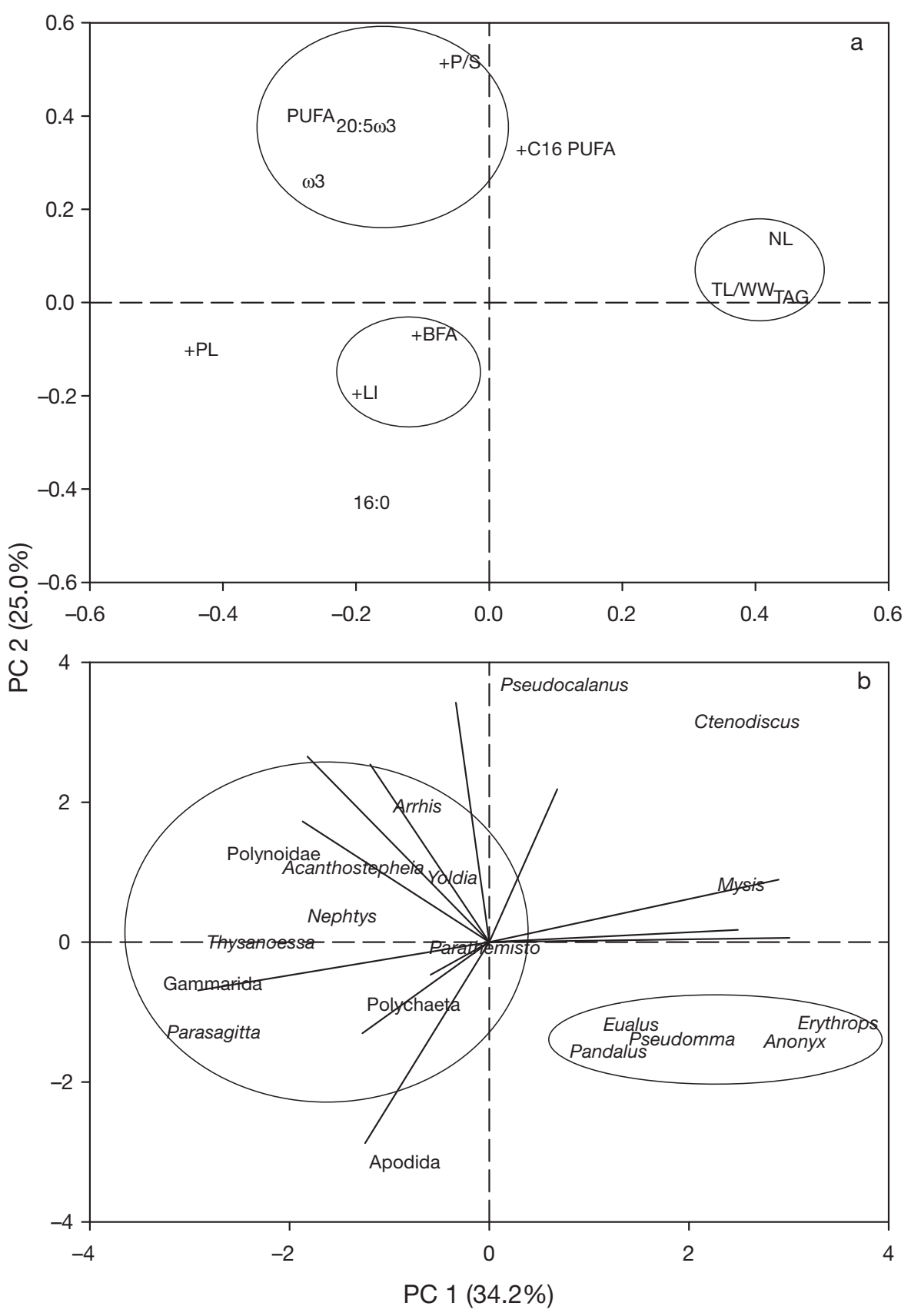

Fig. 3. Principal components analysis (PCA) of lipid concentrations and proportions in benthic and suprabenthic invertebrates from Conception Bay. PCA was performed on the means of the lipid variables in Table 3 plus proportions of 20:5 $03,16: 0$, phospholipid (PL) and triacylglycerol (TAG). Cluster analysis was used to group (a) the coefficients and (b) the scores. The sign of the loading of each variable on PC3 is indicated where positive; the remaining coefficients were negative. Rays drawn to variables in the biplot are scaled according to the loading plot benthic and suprabenthic invertebrates. The apodid holothurian has the most negative PC2 score with the lowest P/S ratio and high 16:0 proportions. Pseudocalanus spp. has the most positive PC2 score with the lowest lipolysis index and bacterial fatty acid proportions, and the highest $\mathrm{C}_{16}$ PUFA proportions. Finally, the predator Parathemisto spp. is located most centrally with values close to the mean for all but one variable, indicating multiple fatty acid sources for this carnivore. This suggests similarities with Parathemisto pacifica collected off British Columbia, whose stomachs contained 12 different prey items (Haro-Garay 2003).

Cluster analysis of the scores of PC1 and PC2 produces 2 groups (Fig. 3b). The largest group, on the negative side of PC1, is characterized by average to high P/S ratios, PUFA and $\omega 3$ fatty acid proportions, and by average to low total lipids, neutral lipids and $\mathrm{C}_{16}$ PUFA. This suggests that the group has high $\omega 3$ fatty acid diets of similar composition, that fatty acids derived from fresh diatom cells were less important and that fewer fatty acids were stored. The smaller group in the lower right quadrant is characterized by average to high total lipid concentrations and neutral lipid proportions, low PUFA content, and average to low $\mathrm{P} / \mathrm{S}$ ratios and proportions of bacterial fatty acids, $\omega 3$ fatty acids, and $\mathrm{C}_{16}$ PUFA. This grouping suggests a good supply of lipids of lower quality. Inclusion of PC3 scores in the cluster analysis grouped Parasagitta elegans and the gammarid together but separate from other taxa, suggesting that the gammarid may feed as a scavenger on dead and dying chaetognaths.

Four taxa did not fall within groups, regardless of whether scores from the first 2 or first 3 principal components were included. Scores for Pseudocalanus spp., Mysis mixta and Ctenodiscus crispatus indicate the importance of fresh diatom material for lipid storage and, in the case of the latter 2 species, for significantly higher lipid concentrations. The location of the holothurian implies a greater dietary 
contribution of saturated and bacterial fatty acids, and a lower contribution of PUFAs.

PCA of lipid concentrations (\% WW) grouped neutral lipids and triacylglycerols together, and phospholipids and 16:0 separately from each other and all other coefficients, as in Fig. 3. Scores for Pseudomma truncatum and Anonyx spp. grouped together and separately from a much larger group containing most of the taxa. Scores for Pseudocalanus spp., Ctenodiscus crispatus and Mysis mixta separated from each other and all other scores, as in Fig. 3b.

\section{Influence of sinking spring bloom material on major lipid groups}

Changes in lipid concentrations and proportions during and after the spring bloom (Figs. 4 to 7 ) suggest that various strategies are used to sequester lipids in suprabenthic and benthic invertebrates, which together may optimize use of the sinking bloom material and explain lower bacterial production rates in the epibenthic flocculent layer (Pomeroy et al. 1991). Only invertebrates for which we have more than 4 time points were plotted, and each time point was statistically compared with the grand mean and the prebloom value. Where significant, regressions were plotted through individual values. Mostly linear regressions are provided, but significant quadratic and cubic regressions are also plotted as a visual guide.

Total lipid concentrations were generally higher within 9 wk of the beginning of the bloom and/or more than 16 wk after the start (Fig. 4). Of the 8 taxa, the chaetognath Parasagitta elegans showed the lowest variability in total lipid content $(41.3 \% \mathrm{CV})$. This suggests that this gelatinous carnivore, which is found in high concentrations in the hyperbenthic zone (Choe \& Deibel 2000), is the furthest removed from direct linkage with phytodetritus from the sinking spring diatom bloom. Similarly, Mysis mixta demonstrated relatively low variability in total lipid content, suggesting opportunistic omnivory as has been reported previously for Conception Bay and elsewhere (Richoux et al. 2005). In contrast, Yoldia hyperborea and the gonad of Ctenodiscus crispatus showed the highest variability ( $\geq 49.6 \% \mathrm{CV}$ ). Highly variable lipid concentrations in gonad tissue (Fig. 4, Table 6) are consistent with a gametogenic cycle, and both digestive and reproductive processes in $Y$. hyperborea depend strongly on input of fresh algal material, despite the availability of high concentrations of sedimentary organic matter (Stead \& Thompson 2003, Jaramillo \& Thompson 2008). Furthermore, Christensen \& Kanneworff (1985) have also questioned the importance of bacteria and detritus for deposit feeders. Taken together, these observations underline the significance of food quality as well as food quantity in the nutrition of benthic invertebrates.

The amphipods Anonyx spp. and Acanthostepheia malmgreni responded to the spring bloom with generally higher total lipid concentrations during the 3 to 9 wk period after the start of the bloom (Fig. 4). Hill et al. (1992) demonstrated increased lipid concentrations in 2 species of deposit-feeding amphipods in the Baltic during and after the spring bloom, and attributed variation in the magnitude and duration of the increases to differences in feeding and metabolic rates. For Anonyx spp., the maximum observed concentration coincided with the bloom maximum in surface waters $25 \mathrm{~d}$ after the bloom started in 1997 ( $\mathrm{p}=0.04$; Fig. 4); however, A. malmgreni, the decapod Pandalus borealis, and especially the mysid Pseudomma truncatum also showed increases beginning 16 to 20 wk after the bloom start. This may represent reproduction based on photosynthate originally generated during the spring bloom or towards the end of the time series. Seasonal cycles of total lipid content in benthic shrimp and prawn species have previously been attributed to gametogenesis, rather than to fluctuations in food availability (Clarke 1977, 1979).

Acanthostepheia malmgreni is a thoracic brooder, protecting spawned eggs within the brood pouch of the female, where development occurs. Mature females usually dominate in Conception Bay epibenthic sled samples from the end of February until the end of April, and spent females often dominate in May (Richoux et al. 2004b). The unusually low total lipid concentrations (Fig. 4) and neutral lipid proportions (Fig. 5) in the specimens from May 1997, $38 \mathrm{~d}$ after the start of the bloom, suggest that these were spent females. Immature males and females, which can dominate in the summer (Richoux et al. 2004b), may have taken advantage of the secondary bloom occurring at that time (Fig. 2) to increase lipid storage (Figs. 4 \& 5). Such a summer pulse also occurred in Conception Bay in 1999 (Richoux et al. 2004a).

Fig. 5 shows the neutral lipid content of invertebrates during and after the spring blooms in Conception Bay. Again, Student's $t$-tests show that there were generally higher neutral lipid proportions beginning within $7 \mathrm{wk}$ of the bloom start and/or higher proportions more than $16 \mathrm{wk}$ after the bloom start, which suggests that there were generally more lipids stored during these periods. In contrast with total lipid concentrations, the chaetognath Parasagitta elegans showed the highest variability in neutral lipid proportions $(51.0 \% \mathrm{CV})$. P. elegans reproduces in summer and fall (Choe \& Deibel 2000), apparently using neutral lipid stores to supply gametogenesis (Fig. 5). The decline in neutral lipids over the summer and the very 

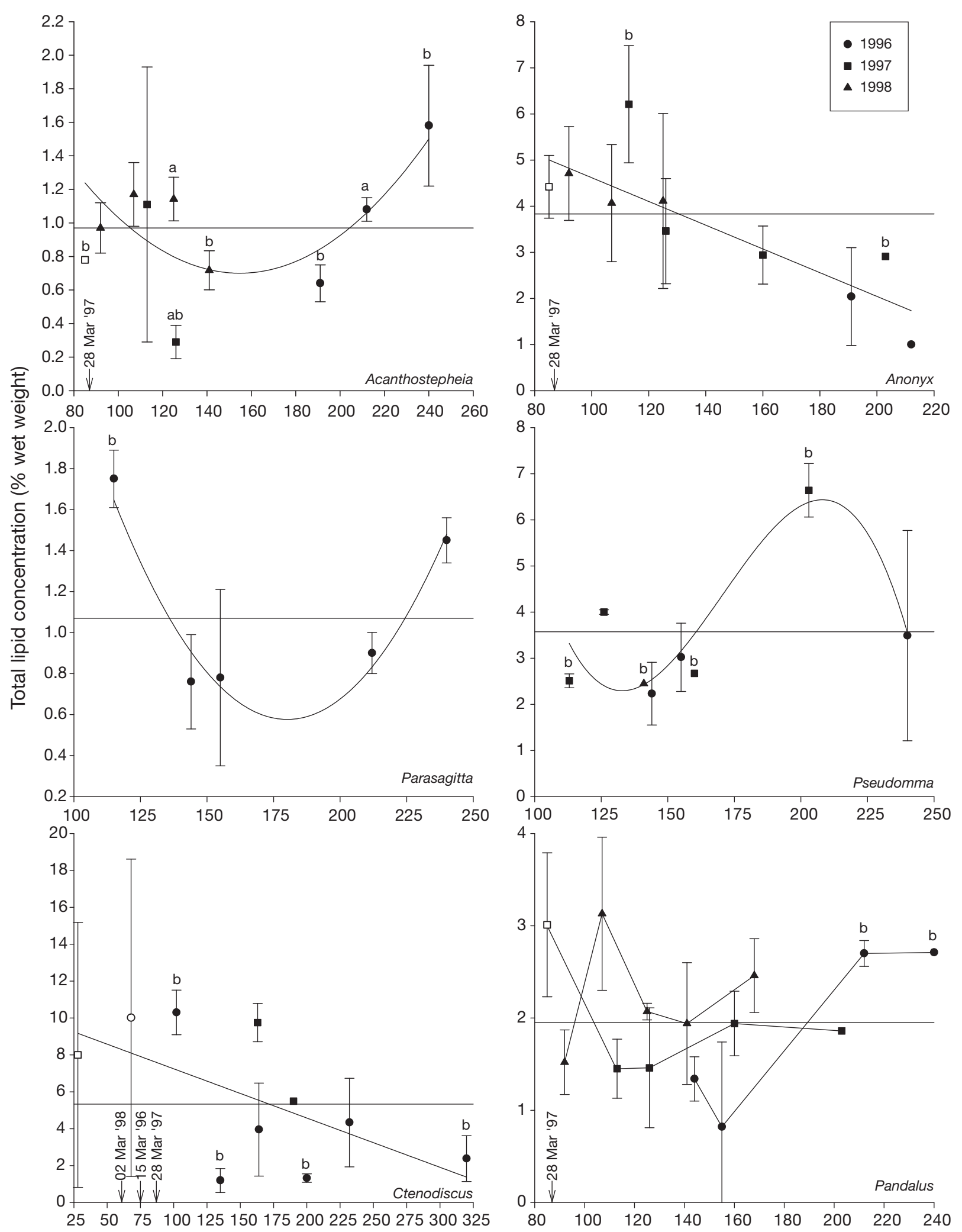

Day of year

Fig. 4. Total lipid concentration (\% wet weight) in suprabenthic and benthic invertebrates during and after spring blooms in Conception Bay, Newfoundland. All means (horizontal lines) and regression lines (linear or polynomial regression) are plotted through the raw data. Data for each sampling day are shown as mean \pm SD. Note different scales for most plots. Arrows indicate day/date of bloom initiation. Open symbols are samples collected before bloom initiation. Acanthostepheia malmgreni: $\mathrm{r}=0.47$, $\mathrm{n}=30, \mathrm{p}=0.033$; Anonyx spp.: $\mathrm{r}=0.62, \mathrm{n}=20, \mathrm{p}=0.003$; Parasagitta elegans: $\mathrm{r}=0.83, \mathrm{n}=11, \mathrm{p}=0.009$; Pseudomma truncatum:

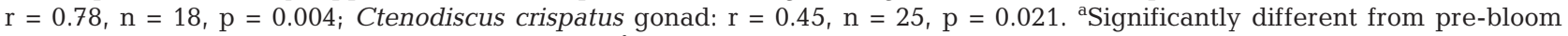
concentration; ${ }^{b}$ significantly different from overall mean 

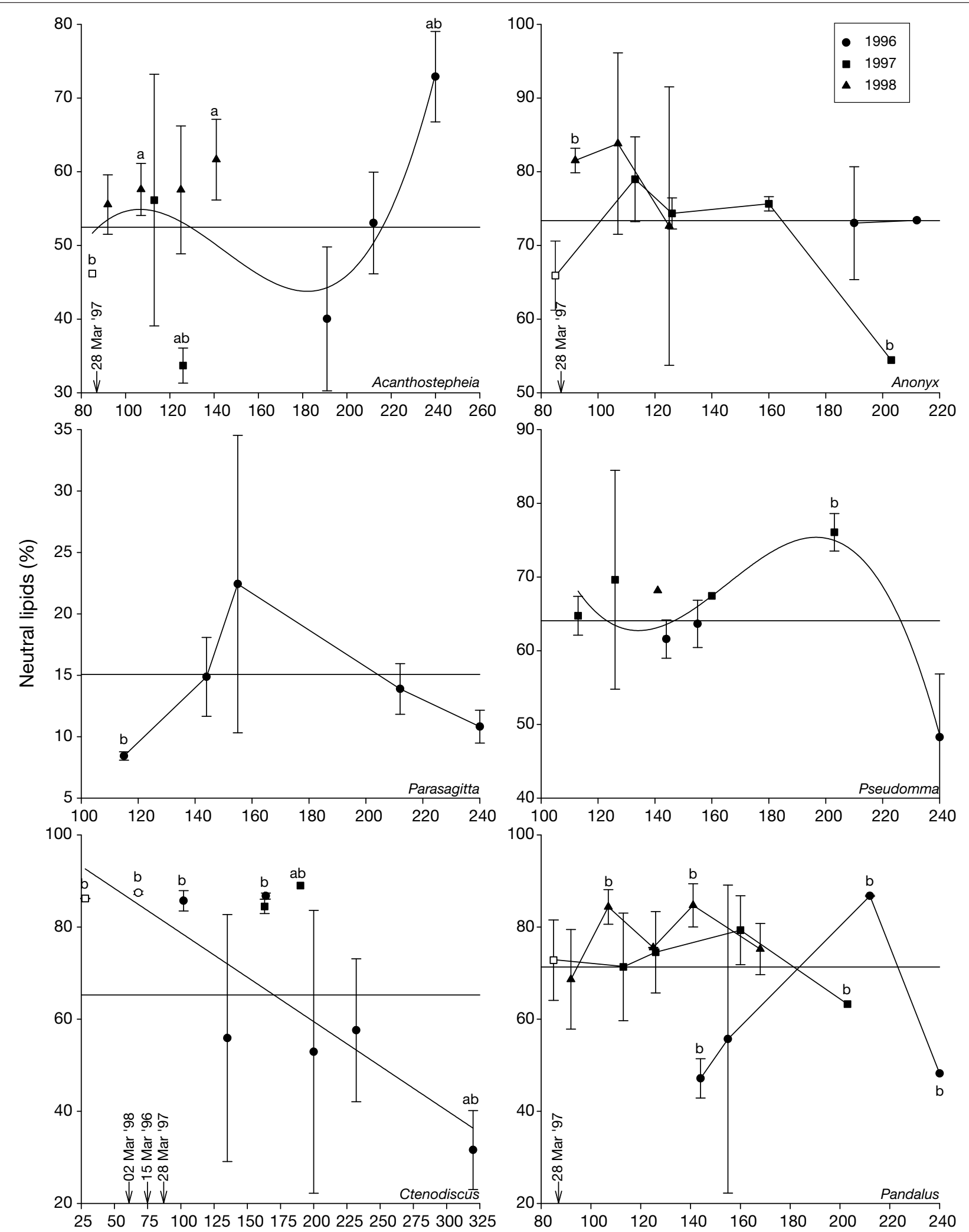

Day of year

Fig. 5. Neutral lipid proportion in suprabenthic and benthic invertebrates during and after spring blooms in Conception Bay, Newfoundland. All means (horizontal lines) and regression lines (linear or polynomial regressions) are plotted through the raw data. Data for each sampling day are shown as mean \pm SD. Note different scales for most plots. Arrows indicate day/date of bloom initiation. Open symbols are samples collected before bloom initiation. Acanthostepheia malmgreni: $\mathrm{r}=0.55, \mathrm{n}=30, \mathrm{p}=0.023$; Pseudomma truncatum: $\mathrm{r}=0.77, \mathrm{n}=18, \mathrm{p}=0.005$; Ctenodiscus crispatus gonad: $\mathrm{r}=0.61, \mathrm{n}=25, \mathrm{p}=0.001$. ${ }^{\mathrm{a}}$ Significantly different from pre-bloom proportion; ${ }^{\mathrm{b}}$ significantly different from overall mean 
low value in spring meant that $P$. elegans had by far the lowest seasonal mean proportion (15.1\% TL). Mysis mixta was the opposite (Table 3), having the lowest variability in neutral lipids $(12.9 \% \mathrm{CV})$ and the highest mean neutral lipid content (76.2\% TL). $M$. mixta may display an ontogenetic shift in diet, with copepods becoming an important food source at the end of the summer (Viherluoto et al. 2000) before the annual spawning event.

Acanthostepheia malmgreni and Anonyx spp. responded to the spring bloom by increasing neutral lipid proportions from 4 to $7 \mathrm{wk}$ after the start of the bloom (Fig. 5). In Anonyx spp., maximum observed proportions coincided with the bloom maximum in surface waters in the $2 \mathrm{yr}$ for which we have data for that time of the year (1997 and 1998); however, maximum proportions in A. malmgreni, Pandalus borealis and Pseudomma truncatum occurred 16 to $24 \mathrm{wk}$ after the start of the bloom, which again may relate to reproduction. Presumably, the late summer increase in neutral lipids by A. malmgreni is in preparation for brood production later in the year (Richoux et al. 2004b).

In contrast to the seasonal variation seen in total lipid concentrations and neutral lipid proportions, Anonyx spp. maintained comparatively similar $\omega 3$ fatty acid proportions throughout the sampling period (Fig. 6). On the other hand, Acanthostepheia malmgreni, Yoldia hyperborea, Pandalus borealis and Mysis mixta did respond to the bloom by increasing the proportions of $\omega 3$ fatty acids, while Ctenodiscus crispatus increased $\omega 3$ fatty acid proportions in the gonad much later, when total and neutral lipids were at their lowest. A. malmgreni differed from other species in that it maintained high (38.2\% of total fatty acids) and similar (11.4\% CV) proportions of $\omega 3$ fatty acids throughout the sampling period, suggesting that it is well able to sequester $\omega 3$ fatty acids from its food.

Fig. 7 shows the $\mathrm{C}_{16}$ PUFA ratio in invertebrates during and after the spring bloom in Conception Bay. Mysis mixta shows a very strong positive response to the start of the bloom, whereas Acanthostepheia malmgreni and Ctenodiscus crispatus had high values at the start of the bloom, which then declined over the next few months before increasing again. Parasagitta elegans maintained very similar $\mathrm{C}_{16}$ PUFA ratios (24.9\% CV; Table 3).

Mysis mixta releases juveniles from its brood pouch every year during April/May, after which the adult females die (Richoux et al. 2004a). Immature males and females are the dominant $M$. mixta stages found in Conception Bay epibenthic samples from March to June (Richoux et al. 2004a). This vertically migrating crustacean is apparently well able to assimilate lipids from rapidly growing, nutrient sufficient diatoms (Fig. 7), and can accumulate as much as $4 \%$ of the entire PUFA flux to the benthos (Parrish et al. 2005). Vertically migrating $M$. relicta in Lake Michigan also exhibit a high but variable lipid content which is related to diatom availability (Gardner et al. 1985).

In contrast to the mysid Mysis mixta, the northern shrimp Pandalus borealis generally exhibits lower $\mathrm{C}_{16}$ PUFA ratios during the bloom (Fig. 7). P. borealis, which also migrates vertically, is found in most northern waters and is one of the most important cold-water shrimp species. In the northwest Atlantic, P. borealis catches have been the highest of all Crustacea (Parsons et al. 1998), and the species is important prey for cod off Iceland (Jaworski \& Ragnarsson 2006). While $P$. borealis, like $M$. mixta, has a neutral lipid proportion that is significantly higher than the average of the invertebrate taxa in the present study, its total lipid content is lower than that of $M$. mixta and it has a $\mathrm{C}_{16}$ PUFA ratio significantly lower than average (Table 3 ). This, combined with the lack of response in the $C_{16}$ PUFA ratio (Fig. 7), suggests that the 2 species are feeding at different trophic levels and that $M$. mixta is probably not a major component of the diet of $P$. borealis. The low mean $\mathrm{C}_{16}$ PUFA ratio for $P$. borealis, compared with an over 5-fold higher value for Pseudocalanus spp. (Table 3), suggests that Pseudocalanus spp. is not a major contributor to $P$. borealis' diet either. However, $P$. borealis is carnivorous, since a stable isotope model gives it a trophic level of 2.63 compared with 1.95 to 2.00 in Calanus finmarchicus and $C$. hyperboreus (Rigét et al. 2007). The latter may be a major component of $P$. borealis' diet, as $P$. borealis had by far the highest proportion of $22: 1 \omega 11(4.0 \pm 2.2 \%)$, which is considered to be a marker for C. hyperboreus (Dalsgaard et al. 2003).

The gonad of Ctenodiscus crispatus had the highest mean $\mathrm{C}_{16}$ PUFA ratio (26\%) among the examined taxa (Tables $3 \& 6$ ). This suggests efficient assimilation of bloom material and indicates the importance of newly formed diatom cells to reproduction in this species. Concomitantly, the C. crispatus gonad had the highest mean P/S ratio, which was significantly higher than in the stomach. By contrast, the stomach had a significantly higher lipolysis index and 18:1 isomer ratio than the gonad, reflecting lipid digestion and metabolism. Low $\omega 9 / \omega 7$ ratios in echinoderms have been attributed to elongation of 16:1 1 7 from diatoms to 18:1 107 (Graeve et al. 1997). Of particular significance is that the P/S ratio in the stomach of C. crispatus is still very low compared to the value of 2.4 found in settling particles at $220 \mathrm{~m}$ in Conception Bay, suggesting chain elongation in the stomach and/or a significant intake of bacterial 18:1 1 7. Accumulation of bacterial fatty acids is consistent with $C$. crispatus being a nonselective detritivore consuming bulk sediment and its attached microflora (Shick et al. 1981). 

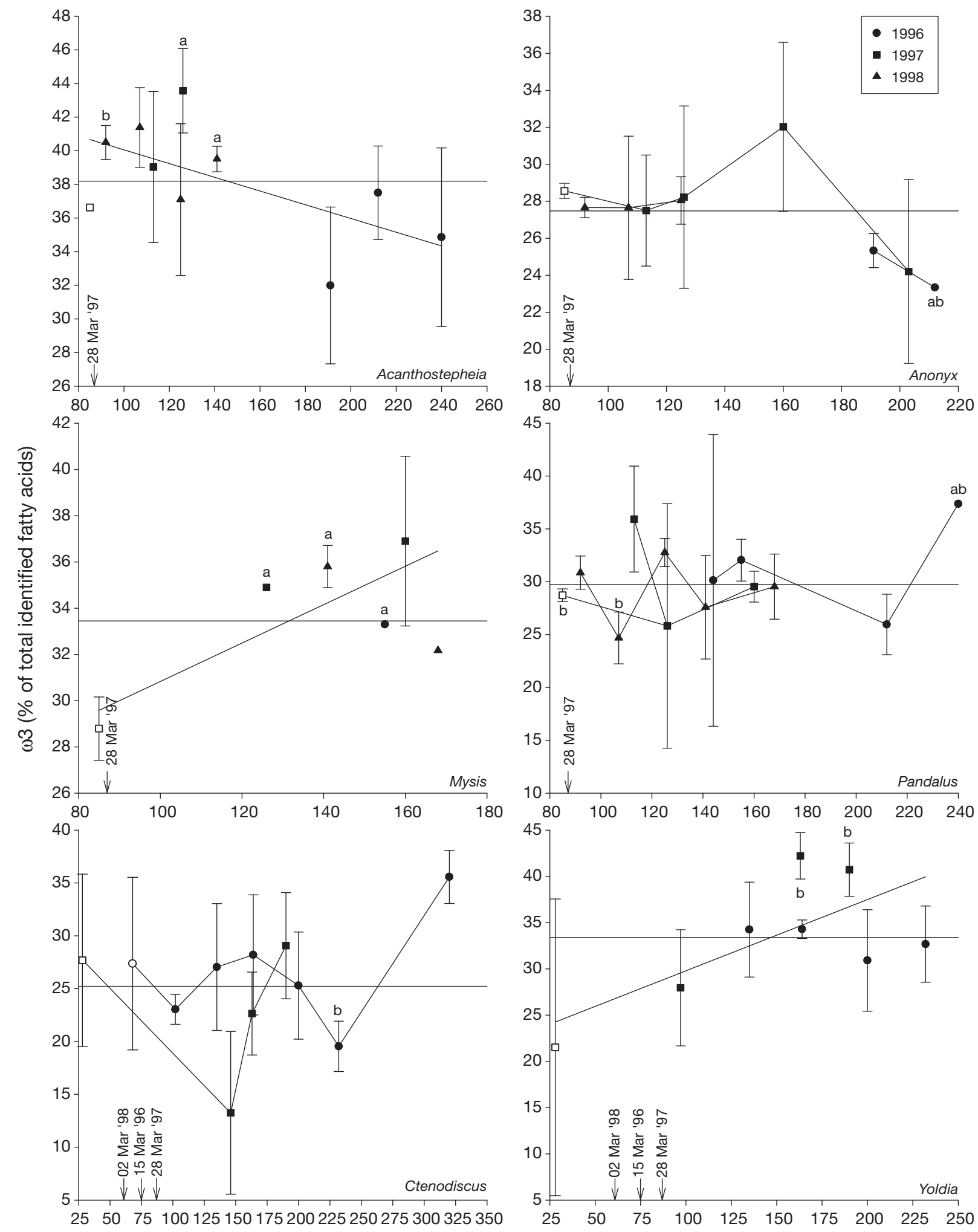

Day of year

Fig. 6. $\omega 3$ fatty acid proportions in suprabenthic and benthic invertebrates during and after spring blooms in Conception Bay, Newfoundland. All means (horizontal lines) and regression lines (linear or polynomial regressions) are plotted through the raw data. Data for each sampling day are shown as mean \pm SD. Note different scales for most plots. Arrows indicate day/date of bloom initiation. Open symbols are samples collected before bloom initiation. Acanthostepheia malmgreni: $\mathrm{r}=0.47, \mathrm{n}=29, \mathrm{p}=0.010$;

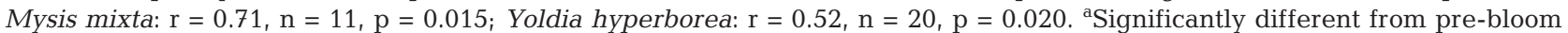
proportion; ${ }^{b}$ significantly different from overall mean 


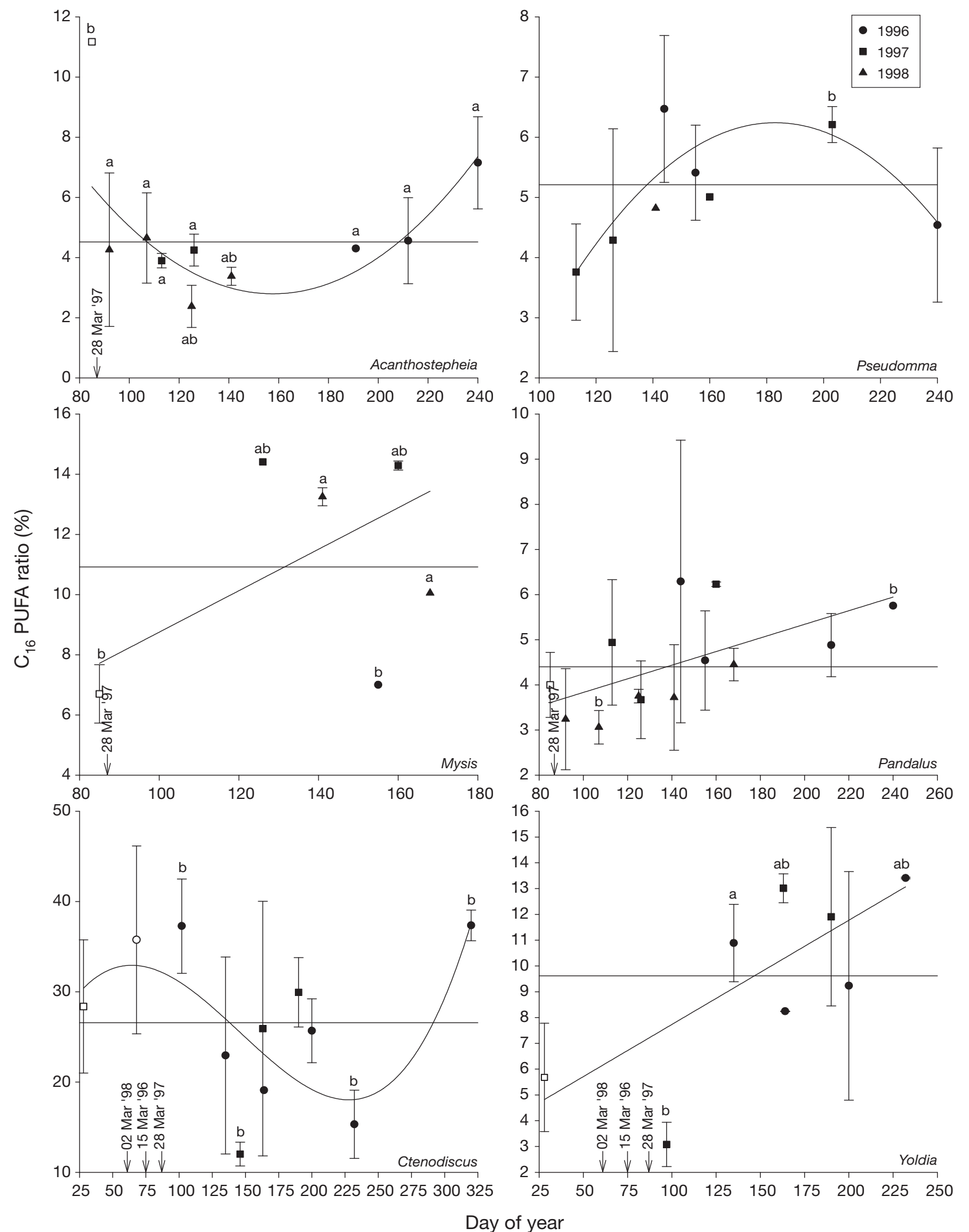

Fig. 7. $\mathrm{C}_{16}$ PUFA ratio in suprabenthic and benthic invertebrates during and after spring blooms in Conception Bay, Newfoundland. All means (horizontal lines) and regression lines (linear or polynomial regressions) are plotted through the raw data. Data for each sampling day are shown as mean $\pm \mathrm{SD}$. Note different scales for most plots. Arrows indicate day/date of bloom initiation. Open symbols are samples collected before bloom initiation. Acanthostepheia malmgreni: $\mathrm{r}=0.64, \mathrm{n}=29, \mathrm{p}=0.001 ;$ Pseudomma truncatum: $\mathrm{r}=0.57, \mathrm{n}=18, \mathrm{p}=0.049 ;$ Mysis mixta: $\mathrm{r}=0.64, \mathrm{n}=11, \mathrm{p}=0.035$; Pandalus borealis: $\mathrm{r}=0.38, \mathrm{n}=33, \mathrm{p}=0.030$; Ctenodiscus crispatus gonad: $\mathrm{r}=0.54, \mathrm{n}=28, \mathrm{p}=0.035$; Yoldia hyperborea: $\mathrm{r}=0.64, \mathrm{n}=20, \mathrm{p}=0.002$. ${ }^{\text {Significantly different from }}$ pre-bloom ratio; ${ }^{\mathrm{b}}$ significantly different from overall mean 


\section{CONCLUSIONS}

In 1996 to 1998, the spring diatom bloom in Conception Bay reached a peak in April and there was a variable response to the sinking phytodetritus among 19 taxa of suprabenthos and benthos, dependent on feeding behavior and gonadogenesis. Mysids, the amphipod Anonyx spp. and Ctenodiscus crispatus showed the highest levels of total and neutral lipids. In Anonyx spp., the highest levels occurred 4 to 6 wk after the start of the spring bloom. By contrast, maximum amounts in Acanthostepheia malmgreni, Pandalus borealis and Pseudomma truncatum occurred 4 to 5 mo after the start of the bloom.

Thysanoessa raschii and the amphipods had the highest proportions of $\omega 3$ fatty acids overall. In Acanthostepheia malmgreni, the highest proportions occurred $5 \mathrm{wk}$ after the start of the bloom, whereas Ctenodiscus crispatus increased $\omega 3$ fatty acid proportions in the gonad 8 mo after the start of the spring bloom, when neutral lipid proportions were much lower. Overall, the gonad of Ctenodiscus crispatus had the highest mean $\mathrm{C}_{16}$ PUFA ratio, suggesting efficient assimilation of bloom material and indicating the importance of newly formed diatom cells to reproduction in this species.

PCA grouped the polynoids and the crustaceans Acanthostepheia malmgreni, Arrhis phyllonyx, Gammaridae sp., Parathemisto spp. and Thysanoessa raschii together because of their similar mean lipid proportions. They had higher PUFA and $\omega 3$ fatty acids but lower $\mathrm{C}_{16}$ PUFA ratios and neutral lipid proportions than the means for the 19 taxa in Conception Bay. This suggests that, although they had access to high quality lipids, those derived from fresh diatom cells were comparatively less important, and fewer fatty acids were stored. Parathemisto spp. was located centrally in the PCA, indicating multiple lipid sources for this carnivore. PCA scores for Mysis mixta and Ctenodiscus crispatus indicate the importance of fresh diatom material for lipid storage. Scores for Anonyx spp., Erythrops erythrophtalma and Pseudomma truncatum reflect significantly higher lipid concentrations but significantly lower PUFA proportions and P/S ratios, suggesting a good supply of lipids of lower quality.

Thus, various strategies are used to sequester essential fatty acids and high energy algal lipids at different trophic levels. Differences often occur among taxa within a phylum and even within orders. Together, these strategies may optimize use of the sinking bloom material for the entire community in a cold ocean environment where lipid fluxes are seasonally high but sediment lipid concentrations are low.
Acknowledgements. We thank the captain and crew of the RV 'Karl and Jackie II' and the MV 'Nain Banker', and Elizabeth Hatfield, Michael Riehl, and Jeanette Wells for technical support in all aspects of this work. We also thank N. Richoux and $\mathrm{N}$. Choe for their assistance in the collection and sorting of suprabenthos. This work was funded through a Natural Science and Engineering Research Council of Canada Collaborative Project Grant.

\section{LITERATURE CITED}

Ackman RG (1986) WCOT (capillary) gas-liquid chromatography. In: Hamilton RJ, Rossell JB (eds) Analysis of oils and fats, Elsevier, New York, p 137-206

Ackman RG, Kean-Howie J (1994) Fatty acids in aquaculture: Are $\omega-3$ fatty acids always important? In: Lim C, Sessa DJ (eds) Nutrition and utilization technology in aquaculture, AOCS Press, Champaign, IL, p 82-104

Alkanani T, Parrish CC, Thompson RJ, McKenzie CH (2007) Role of fatty acids in cultured mussels, Mytilus edulis, grown in Notre Dame Bay, Newfoundland. J Exp Mar Biol Ecol 348:33-45

Billones RG, Tackx MLM, Flachier AT, Zhu L, Daro MH (1999) Image analysis as a tool for measuring particulate matter concentrations and gut content, body size, and clearance rates of estuarine copepods: validation and application. J Mar Syst 22:179-194

Blankenship LE, Levin LA (2007) Extreme food webs: Foraging strategies and diets of scavenging amphipods from the ocean's deepest 5 kilometers. Limnol Oceanogr 52: 1685-1697

Budge SM, Parrish CC (1998) Lipid biogeochemistry of plankton, settling matter and sediments in Trinity Bay, Newfoundland. II. Fatty acids. Org Geochem 29: $1547-1559$

Choe N, Deibel D (2000) Seasonal vertical distribution and population dynamics of the chaetognath Parasagitta elegans in the water column and hyperbenthic zone of Conception Bay, Newfoundland. Mar Biol 137:847-856

Christensen H, Kanneworff E (1985) Sedimenting phytoplankton as major food source for suspension and deposit feeders in the Oresund. Ophelia 24:223-224

Clarke A (1977) Seasonal variations in the total lipid content of Chorismus antarticus (Pfeffer) (Crustacea: Decapoda) at South Georgia. J Exp Mar Biol Ecol 27:93-106

Clarke A (1979) Lipid content and composition of the pink shrimp, Pandalus montagui (Leach) (Crustacea: Decapoda). J Exp Mar Biol Ecol 38:1-17

Conover RJ, Huntley M (1991) Copepods in ice-covered seas - distribution, adaptations to seasonally limited food, metabolism, growth patterns and life cycle strategies in polar seas. J Mar Syst 2:1-41

> Copeman LA, Parrish CC (2003) Marine lipids in a cold coastal ecosystem: Gilbert Bay, Labrador. Mar Biol 143: 1213-1227

Copeman LA, Parrish CC, Brown JA, Harel M (2002) Effects of docosahexaenoic, eicosapentaenoic, and arachidonic acids on the early growth, survival, lipid composition and pigmentation of yellowtail flounder (Limanda ferruginea): a live food enrichment experiment. Aquaculture 210: 285-304

Cotonnec G, Brunet C, Sautour B, Thoumelin G (2001) Nutritive value and selection of food particles by copepods during a spring bloom of Phaeocystis sp. in the English Channel, as determined by pigment and fatty acid analyses. J Plankton Res 23:693-703 
Cripps GC, Atkinson A (2000) Fatty acid composition as an indicator of carnivory in Antarctic krill, Euphausia superba. Can J Fish Aquat Sci 57:31-37

Dalsgaard J, St. John M, Kattner G, Müller-Navarra D, Hagen W (2003) Fatty acid trophic markers in the pelagic marine environment. Adv Mar Biol 46:225-340

> Dwyer KS, Parrish CC, Brown JA (2003) Lipid composition of yellowtail flounder (Limanda ferruginea) in relation to dietary lipid intake. Mar Biol 143:659-667

Falk-Petersen IB, Sargent JR (1982) Reproduction of asteroids from Balsfjorden, northern Norway: Analyses of lipids in the gonads of Ctenodiscus crispatus, Asterias lincki and Pteraster militaris. Mar Biol 69:291-298

Falk-Petersen S, Gatten RR, Sargent JR, Hopkins CCE (1981) Ecological investigations on the zooplankton community in Balsfjorden, northern Norway: seasonal changes in the lipid class composition of Meganyctiphanes norvegica (M. Sars), Thysanoessa raschii (M. Sars), and T. inermis (Kroyer). J Exp Mar Biol Ecol 54:209-224

Falk-Petersen S, Sargent JR, Tande KS (1987) Lipid composition of zooplankton in relation to the sub-arctic food web. Polar Biol 8:115-120

Falk-Petersen S, Hagen W, Kattner G, Clarke A, Sargent J (2000) Lipids, trophic relationships, and biodiversity in Arctic and Antarctic krill. Can J Fish Aquat Sci 57: 178-191

Fraser AJ, Sargent JR, Gamble JC (1989) Lipid class and fatty acid composition of Calanus finmarchicus (Gunnerus), Pseudocalanus sp. and Temora longicornis Muller from a nutrient-enriched seawater enclosure. J Exp Mar Biol Ecol 130:81-92

Gardner WS, Nalepa TF, Frez WA, Cichocki EA, Landrum PF (1985) Seasonal patterns in lipid content of Lake Michigan macroinvertebrates. Can J Fish Aquat Sci 42:1827-1832

Graeve M, Wehrtmann IS (2003) Lipid and fatty acid composition of Antarctic shrimp eggs (Decapoda: Caridea). Polar Biol 26:55-61

Graeve M, Kattner G, Piepenburg D (1997) Lipids in Arctic benthos: does the fatty acid and alcohol composition reflect feeding and trophic interactions? Polar Biol 18: $53-61$

Hall JM, Parrish CC, Thompson RJ (2002) Eicosapentaenoic acid regulates scallop (Placopecten magellanicus) membrane fluidity in response to cold. Biol Bull 202:201-203

> Haro-Garay M (2003) Diet and functional morphology of the mandible of 2 planktonic amphipods from the Strait of Georgia, British Columbia, Parathemisto pacifica (Stebbing, 1888) and Cyphocaris chellengeri (Stebbing, 1888). Crustaceana 76:1291-1312

Henderson RJ, Falk-Petersen S, Sargent JR (1982) The composition and biosynthesis of lipids in Thysanoessa raschi from the Clyde Estuary, Scotland. Mar Biol 70:7-12

Hill C, Quigley MA, Cavaletto JF, Gordon W (1992) Seasonal changes in lipid content and composition in the benthic amphipods Monoporeia affinis and Pontoporeia famorata. Limnol Oceanogr 37:1280-1289

Hu FB, Manson JE, Willet WC (2001) Types of dietary fat and risk of coronary heart disease: a critical review. J Am Coll Nutr 20:5-19

Jaramillo JR, Thompson RJ (2008) The reproductive response of the protobranch bivalve Yoldia hyperobrea to an intermittent influx of phytodetritus. An experimental approach. J Exp Mar Biol Ecol 357:57-63

> Jaworski A, Ragnarsson SA (2006) Feeding habits of demersal fish in Icelandic waters: a multivariate approach. ICES J Mar Sci 63:1682-1694
Koski M, Breteler WK, Schogt N (1998) Effect of food quality on rate of growth and development of the pelagic copepod Pseudocalanus elongatus (Copepoda, Calanoida). Mar Ecol Prog Ser 170:169-187

Lehtonen KK (1996) Ecophysiology of the benthic amphipod Monoporeia affinis in an open-sea area of the northern Baltic Sea: seasonal variations in body composition, with bioenergetic considerations. Mar Ecol Prog Ser 143:87-98

Martínez-Murillo de las Nieves M, Haedrich RL (2007) A perspective on Newfoundland's fisheries ecosystem using size-based food-web relationships. In: Parrish CC, Turner NJ, Solberg SM (eds) Resetting the kitchen table: food security, culture, health and resilience in coastal communities. Nova Science Publishers, Hauppague, NY, p 13-32

McMahon KW, Ambrose WG Jr, Johnson BJ, Sun MY, Lopez GR, Clough LM, Carroll ML (2006) Benthic community response to ice algae and phytoplankton in Ny Alesund, Svalbard. Mar Ecol Prog Ser 310:1-14

Napolitano GE, Ackman RG (1989) Lipids and hydrocarbons in Corophium volutator from Minas Basin, Nova Scotia. Mar Biol 100:333-338

> Neto RR, Wolff GA, Billett DSM, Mackenzie KL, Thompson A (2006) The influence of changing food supply on the lipid biochemistry of deep-sea holothurians. Deep-Sea Res I 53:516-527

Park HG, Puvanendran V, Kellett A, Parrish CC, Brown JA (2006) Effect of enriched rotifers on growth and survival of Atlantic cod (Gadus morhua L.) larvae. ICES J Mar Sci 63:285-295

> Parrish CC (1998) Lipid biogeochemistry of plankton, settling matter and sediments in Trinity Bay, Newfoundland. I. Lipid classes. Org Geochem 29:1531-1545

Parrish CC (1999) Determination of total lipid, lipid classes, and fatty acids in aquatic samples. In: Arts MT, Wainman BC (eds) Lipids in freshwater ecosystems. Springer, New York, p 4-20

Parrish CC, Myher JJ, Kuksis A, Angel A (1997) Lipid structure of rat adipocyte plasma membranes following dietary lard and fish oil. Biochim Biophys Acta 1323:253-262

Parrish CC, Thompson RJ, Deibel D (2005) Lipid classes and fatty acids in plankton and settling matter during the spring bloom in a cold ocean coastal environment. Mar Ecol Prog Ser 286:57-68

Parrish CC, Copeman L, Van Biesen G, Wroblewski J (2007a) Aquaculture and nearshore marine food webs: implications for seafood quality and the environment north of 50 . In: Parrish CC, Turner NJ, Solberg SM (eds) Resetting the kitchen table: food security, culture, health and resilience in coastal communities. Nova Science Publishers, Hauppague, NY, p 33-49

Parrish CC, Whiticar M, Puvanendran V (2007b) Is $\omega 6$ docosapentaenoic acid an essential fatty acid during early ontogeny in marine fauna? Limnol Oceanogr 52:476-479

Parsons DG (2005) Interactions between northern shrimp, Pandalus borealis (Pandalidae), and its key predators within the eastern Newfoundland and Labrador marine ecosystem. Mar Biol Res 1:59-67

Parsons DG, Colbourne EB, Lilly GR, Kulka DW (1998) Northern shrimp (Pandalus borealis) on Flemish Cap (NAFO Division 3M) - oceanography, fishery and biology. J Northwest Atl Fish Sci 24:1-26

Pomeroy LR, Wiebe WJ, Deibel D, Thompson RJ, Rowe GT, Pakulski JD (1991) Bacterial responses to temperature and substrate concentration during the Newfoundland spring bloom. Mar Ecol Prog Ser 75:143-159

> Pond D, Harris R, Head R, Harbour D (1996) Environmental and nutritional factors determining seasonal variability in 
the fecundity and egg viability of Calanus helgolandicus in coastal waters off Plymouth, UK. Mar Ecol Prog Ser 143:45-63

Redmond MS, Scott KJ (1989) Amphipod predation by the infaunal polychaete, Nephtys incisa. Estuaries 12:205-207

Richoux NB, Deibel D, Thompson RJ (2004a) Population biology of hyperbenthic crustaceans in a cold water environment (Conception Bay, Newfoundland) I. Mysis mixta (Mysidacea). Mar Biol 144:881-894

Richoux NB, Thompson RJ, Deibel D (2004b) Population biology of hyperbenthic crustaceans in a cold water environment (Conception Bay, Newfoundland) II. Acanthostepheia malmgreni (Amphipoda). Mar Biol 144: 895-904

Richoux NB, Deibel D, Thompson RJ, Parrish CC (2005) Seasonal and developmental variation in the fatty acid composition of Mysis mixta (Mysidacea) and Acanthostephia malmgreni (Amphipoda) from the hyperbenthos of a coldocean environment (Conception Bay, Newfoundland). J Plankton Res 27:719-733

Rigét F, Moller P, Dietz R, Nielsen TG and others (2007) Transfer of mercury in the marine food web of west Greenland. J Environ Monit 9:877-883

Sargent JR, Falk-Petersen S (1981) Ecological investigations on the zooplankton community in Balsfjorden, northern Norway: lipids and fatty acids in Meganyctiphanes norvegica, Thysanoessa raschi, and T. inermis during midwinter. Mar Biol 62:131-137

Sargent JR, Falk-Petersen IB, Calder AG (1983) Fatty acid compositions of neutral glycerides from the ovaries of the asteroids Ctenodiscus crispatus, Asterias lincki and Pteraster militaris from Balsfjorden, northern Norway. Mar Biol 72:257-264

Scott CL, Falk-Petersen S, Sargent JR, Hop H, Lonne OJ, Poltermann M (1999) Lipids and trophic interactions of ice fauna and pelagic zooplankton in the marginal ice zone of the Barents Sea. Polar Biol 21:65-70

Editorial responsibility: Hans Heinrich Janssen, Oldendorf/Luhe, Germany
Shick JM, Edwards KC, Dearborn JH (1981) Physiological ecology of the deposit-feeding sea star Ctenodiscus crispatus: Ciliated surfaces and animal-sediment interactions. Mar Ecol Prog Ser 5:165-184

Shin KH, Hama T, Yoshie N, Noriki S, Tsunogai S (2000) Dynamics of fatty acids in newly biosynthesized phytoplankton cells and seston during a spring bloom off the west coast of Hokkaido Island, Japan. Mar Chem 70:243-256

Spalding MD, Fox HE, Allen GR, Davidson N and others (2007) Marine ecoregions of the world: A bioregionalization of coastal and shelf areas. Bioscience 57:573-583

Stead RA, Thompson RJ (2003) The effect of the sinking spring diatom bloom on digestive processes of the coldwater protobranch Yoldia hyperborea. Limnol Oceanogr 48:157-167

> Thompson RJ, Deibel D, Redden AM, McKenzie CH (2008) Vertical flux and fate of particulate matter in a Newfoundland fjord at sub-zero water temperatures during spring. Mar Ecol Prog Ser 357:33-49

Tlusty MF, Pepper VA, Anderson MR (2005) Reconciling aquaculture's influence on the water column and benthos of an estuarine fjord-a case study from Bay d'Espoir, Newfoundland. Handb Environ Chem 5:115-128

Viherluoto M, Kuoso H, Flinkman J, Viitasalo M (2000) Food utilization of pelagic mysids, Mysis mixta and M. relicta, during their growing season in the northern Baltic Sea. Mar Biol 136:553-559

> Wassmann P (1997) Retention versus export food chains: processes controlling sinking loss from marine pelagic systems. Hydrobiologia 363:29-57

Xu XL, Ji WJ, Castell JD, O'Dor RK (1994) Essential fatty acid requirement of the Chinese prawn, Penaeus chinensis. Aquaculture 127:29-40

Young JW, Bradford RW, Lamb TD, Lyne VD (1996) Biomass of zooplankton and micronekton in the southern bluefin tuna fishing grounds off eastern Tasmania, Australia. Mar Ecol Prog Ser 138:1-14

Submitted: July 18, 2008; Accepted: June 8, 2009 Proofs received from author(s): September 18, 2009 